University of South Florida

DIGITAL COMMONS

Digital Commons @ University of

@ UNIVERSITY OF SOUTH FLORIDA

South Florida

$1-1-2015$

\title{
2015 Accountability Report USF System
}

USF

Follow this and additional works at: https://digitalcommons.usf.edu/usf_accountability_reports

\section{Scholar Commons Citation}

USF, "2015 Accountability Report USF System" (2015). USF Accountability Reports. 51.

https://digitalcommons.usf.edu/usf_accountability_reports/51

This Article is brought to you for free and open access by the USF Archives at Digital Commons @ University of South Florida. It has been accepted for inclusion in USF Accountability Reports by an authorized administrator of Digital Commons @ University of South Florida. For more information, please contact digitalcommons@usf.edu. 


\section{4-15}

\section{Annual Accountability Report}

\section{UNIVERSITY OF SOUTH FLORIDA SYSTEM}

BOT APPROVED 03/03/2016

STATE UNIVERSITY SYSTEM of FLORIDA Board of Governors 


\section{TABLE OF CONTENTS}

\section{EXECUTIVE SUMMARY}

DASHBOARD

p. 2

PERFORMANCE FUNDING METRICS

p. 5

KEY ACHIEVEMENTS

p. 6

NARRATIVE

p. 8

\section{DATA TABLES}

SECTION 1. FINANCIAL RESOURCES

p. 15

SECTION 2. PERSONNEL

p. 19

SECTION 3. ENROLLMENT

p. 20

SECTION 4. UNDERGRADUATE EDUCATION

p. 24

SECTION 5. GRADUATE EDUCATION

p. 33

SECTION 6. RESEARCH \& ECONOMIC DEVELOPMENT

p. 36 


\section{Dashboard}

\begin{tabular}{|c|c|c|c|c|c|c|c|c|}
\hline $\begin{array}{l}\text { Headcount } \\
\text { Enrollments }\end{array}$ & $\begin{array}{c}\text { Fall } \\
2014\end{array}$ & $\begin{array}{c}\% \\
\text { Total }\end{array}$ & $\begin{array}{l}2013-2014 \\
\% \text { Change }\end{array}$ & \multicolumn{3}{|c|}{ Degree Programs Offered } & \multicolumn{2}{|c|}{2015 Carnegie Classifications } \\
\hline TOTAL & 48,578 & $101 \%$ & $1 \%$ & \multicolumn{2}{|c|}{ TOTAL (as of Sprina 2015) } & 295 & \multirow{2}{*}{ Basic: } & \multirow{10}{*}{$\begin{array}{l}\text { The USF System is } \\
\text { not classified by the } \\
\text { Carnegie Foundation. } \\
\text { The individual campus } \\
\text { reports provide these } \\
\text { classifications. }\end{array}$} \\
\hline White & 26,635 & $55 \%$ & $-3 \%$ & Baccalaureate & & 125 & & \\
\hline Hispanic & 8,328 & $17 \%$ & $3 \%$ & Master's \& Specialis & & 123 & Undergraduate & \\
\hline Black & 4,766 & $10 \%$ & $0 \%$ & Research Doctorate & & 43 & Instructional Program: & \\
\hline Other & 8,849 & $18 \%$ & $12 \%$ & Professional Doctorc & & 4 & \multirow{2}{*}{$\begin{array}{c}\text { Graduate } \\
\text { Instructional Program: }\end{array}$} & \\
\hline Full-Time & 32,806 & $68 \%$ & $1 \%$ & \multirow{2}{*}{$\begin{array}{c}\text { Faculty } \\
\text { (Fall 2014) }\end{array}$} & \multirow{2}{*}{$\begin{array}{l}\text { Full- } \\
\text { Time }\end{array}$} & \multirow{2}{*}{$\begin{array}{l}\text { Part- } \\
\text { Time }\end{array}$} & & \\
\hline Part-Time & 15,772 & $33 \%$ & $0 \%$ & & & & \multirow{2}{*}{ Size and Setting: } & \\
\hline Undergraduate & 35,808 & $74 \%$ & $-1 \%$ & TOTAL & 1,809 & 818 & & \\
\hline Graduate & 10,555 & $22 \%$ & $2 \%$ & Tenure \& Ten. Track & 1,114 & 57 & \multirow{2}{*}{$\begin{array}{l}\text { Community } \\
\text { Engagement: }\end{array}$} & \\
\hline Unclassified & 2,215 & $5 \%$ & $12 \%$ & Non-Tenured Faculty & 695 & 761 & & \\
\hline
\end{tabular}

\section{DEGREE PRODUCTIVITY AND PROGRAM EFFICIENCY}
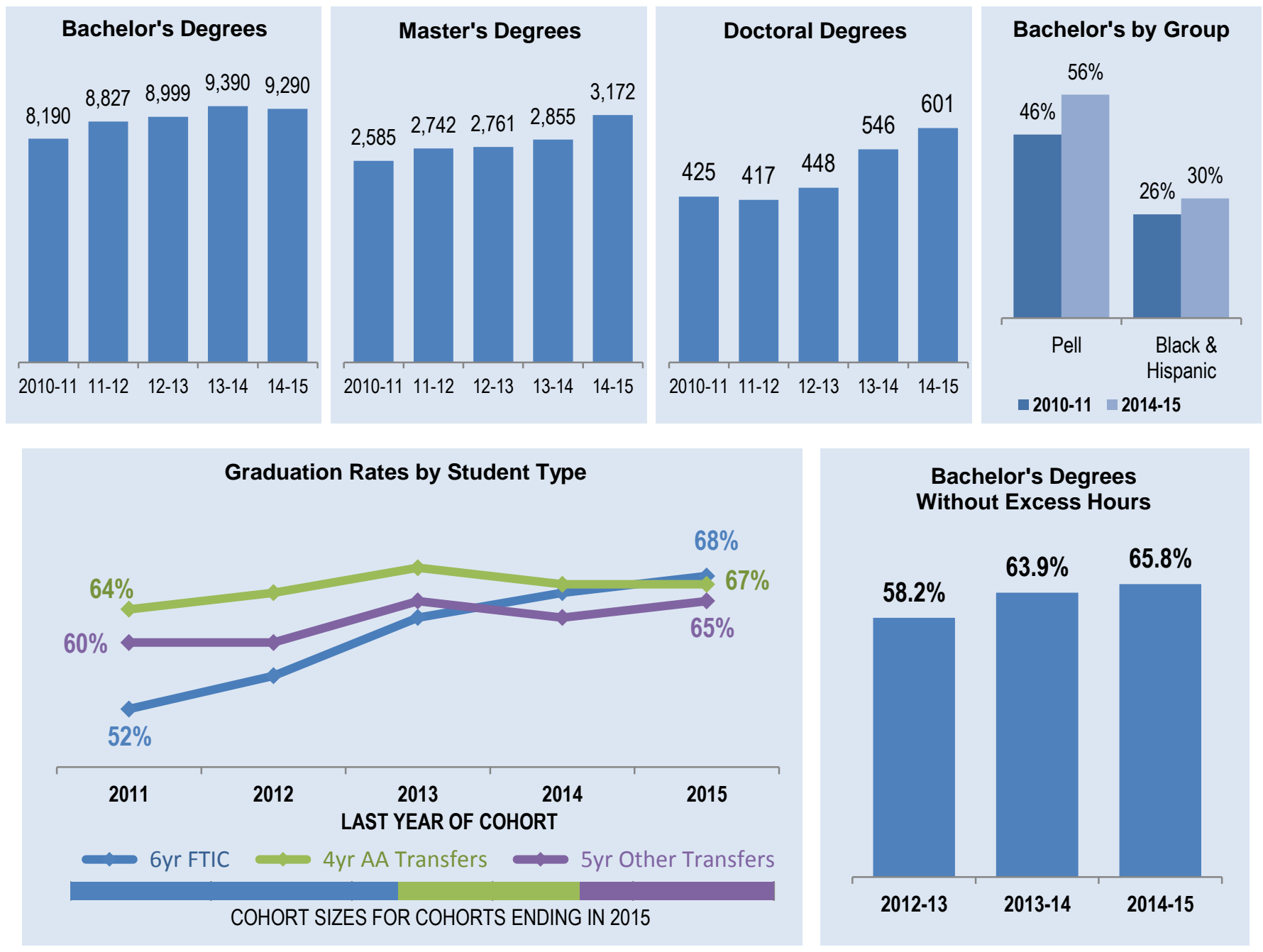


\section{Dashboard}

\section{DEGREES AWARDED IN PROGRAMS OF STRATEGIC EMPHASIS (PSE)}
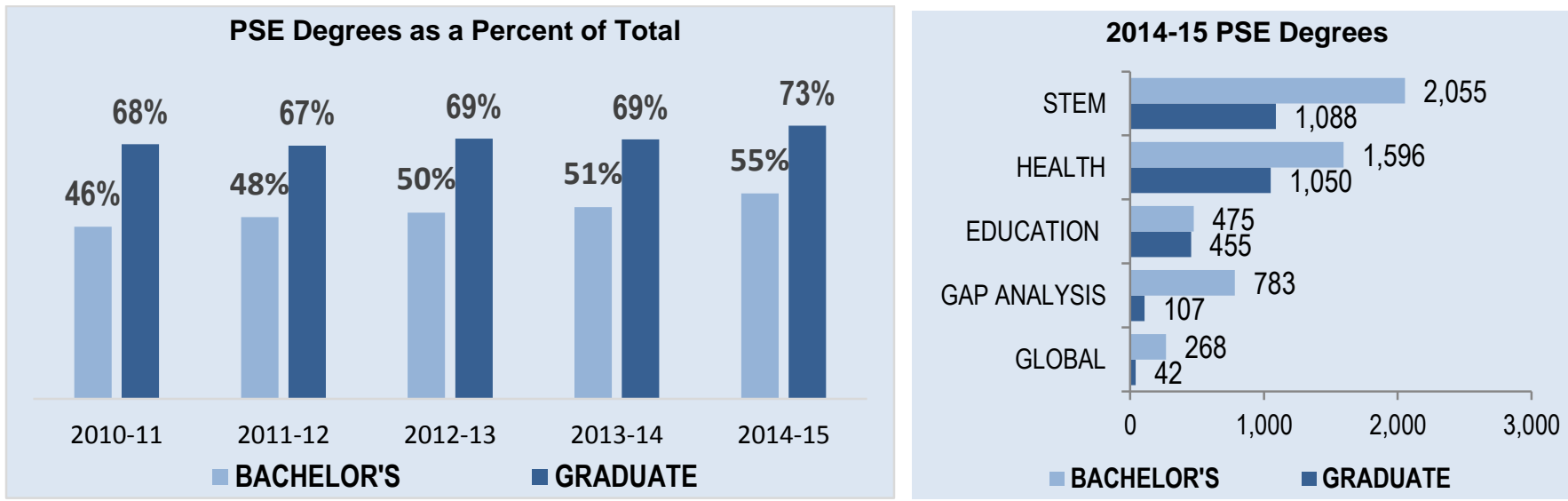

RESEARCH AND COMMERCIALIZATION ACTIVITY
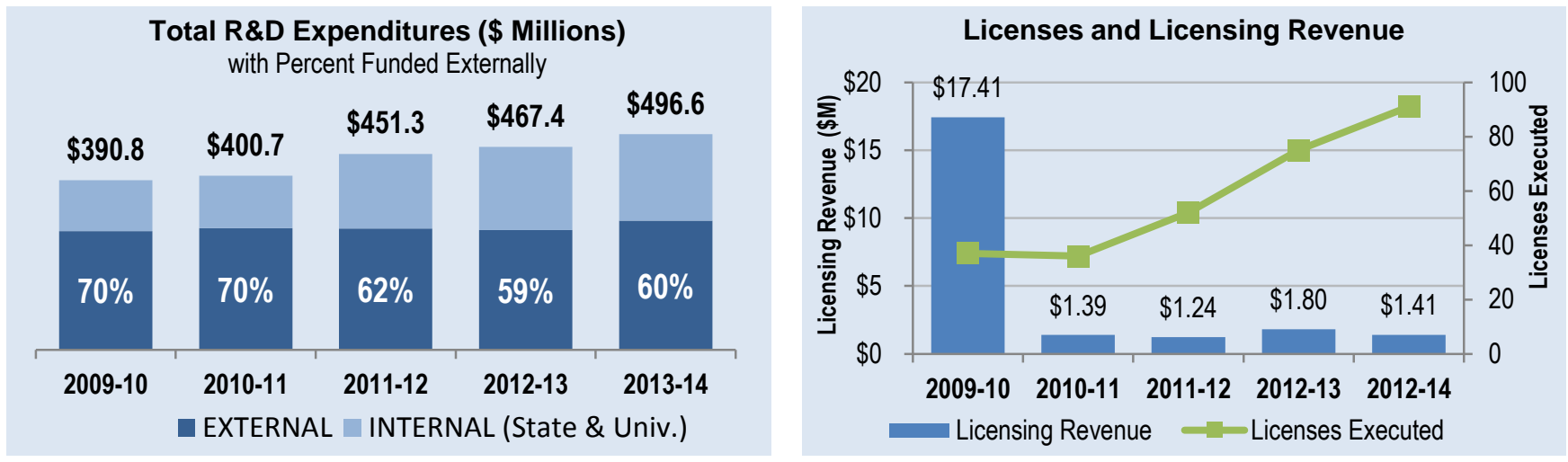

\section{RESOURCES}

\section{ACTUAL FUNDING PER FTE}

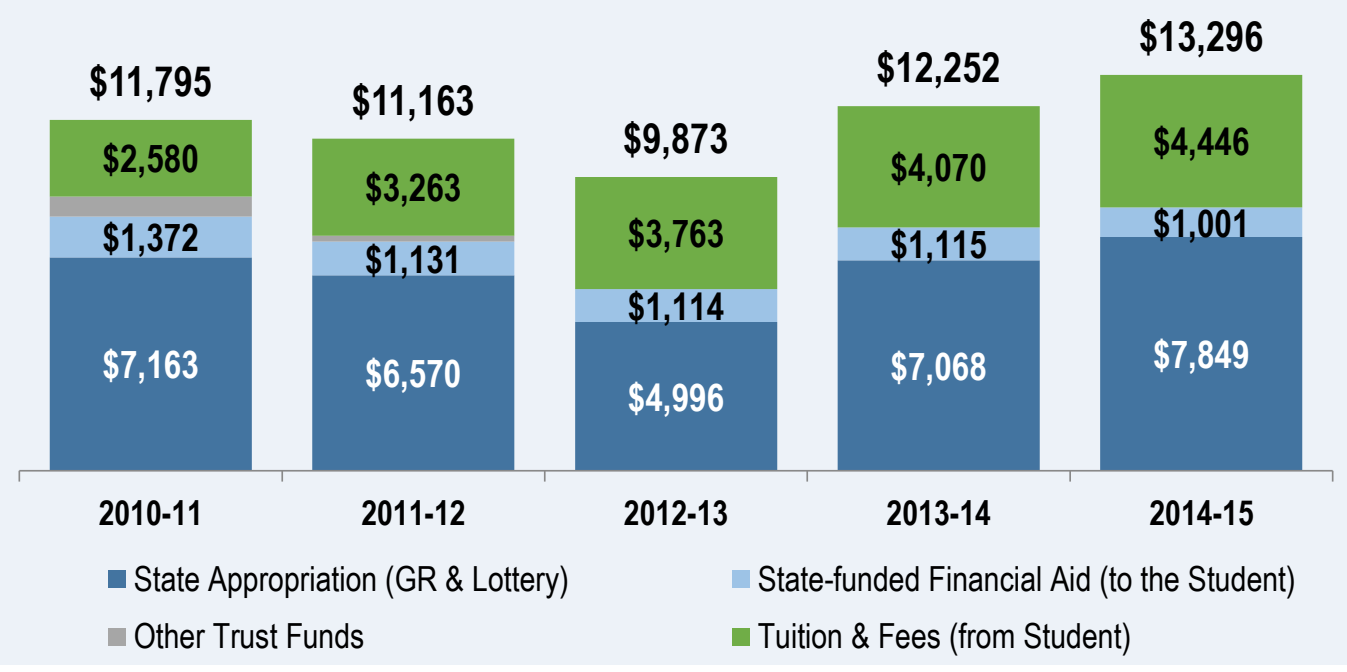

Note: Tuition and Fee revenues include tuition, tuition differential fee and $E \& G$ fees (i.e., application, late registration, and library fees/fines) based on the actual amount collected (not budget authority) by universities as reported in their Operating Budget 625 reports. Other local fees that do not support E\&G activities are not included here. Please note that a portion of the Tuition \& Fees is supported by federal SFA programs (ie, Pell grants). State-funded Student Financial Aid amounts include the 11 SFA programs that OSFA reports annually. State Appropriations includes General Revenues, Lottery and Othe Trust funds (i.e., Federal Stimulus for 2009-10 and 2010-11 only) that are directly appropriated to the university as reported in Final Amendment Package. Student FTE are actual and based on the standard IPEDS definition of FTE (equal to 30 credit hours for undergraduates and 24 for graduates). This data does not include funds or FTE from special units (i.e., IFAS, Health-Science Centers or Medical Schools). Not adjusted for inflation. 


\section{Dashboard}

\section{POST-GRADUATION METRICS}

\section{Percent of Bachelor's Graduates Employed or Continuing their Education One Year After Graduation}

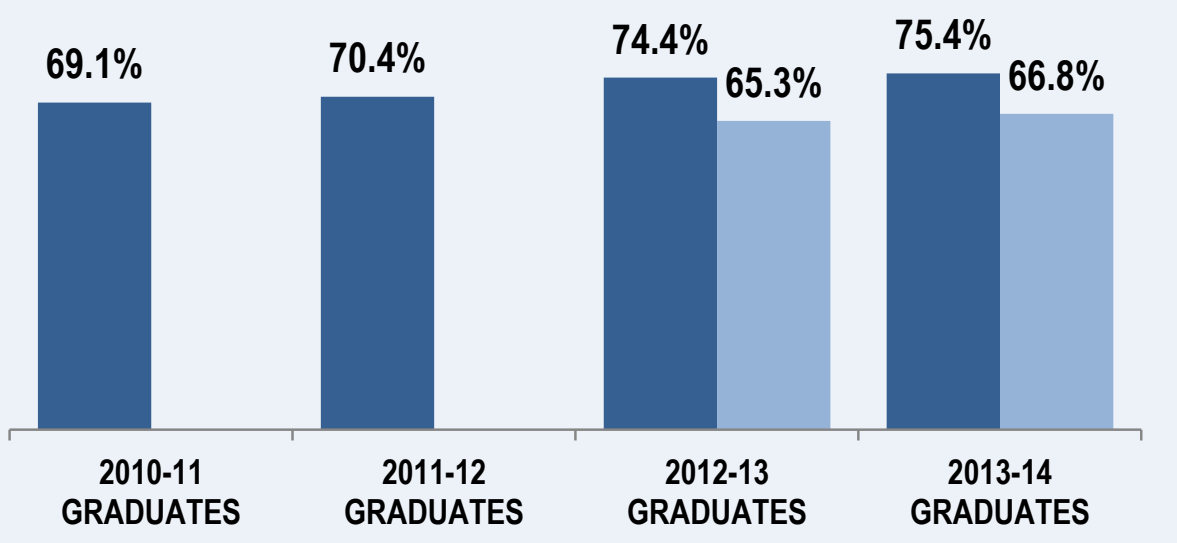

- Enrolled or Employed (Full-time) - Enrolled or Employed (Earning \$25,000+)

\section{Wages of Full-time Employed in Florida Baccalaureates One Year After Graduation 5th, 25th, 50th, 75th and 95th Percentiles}

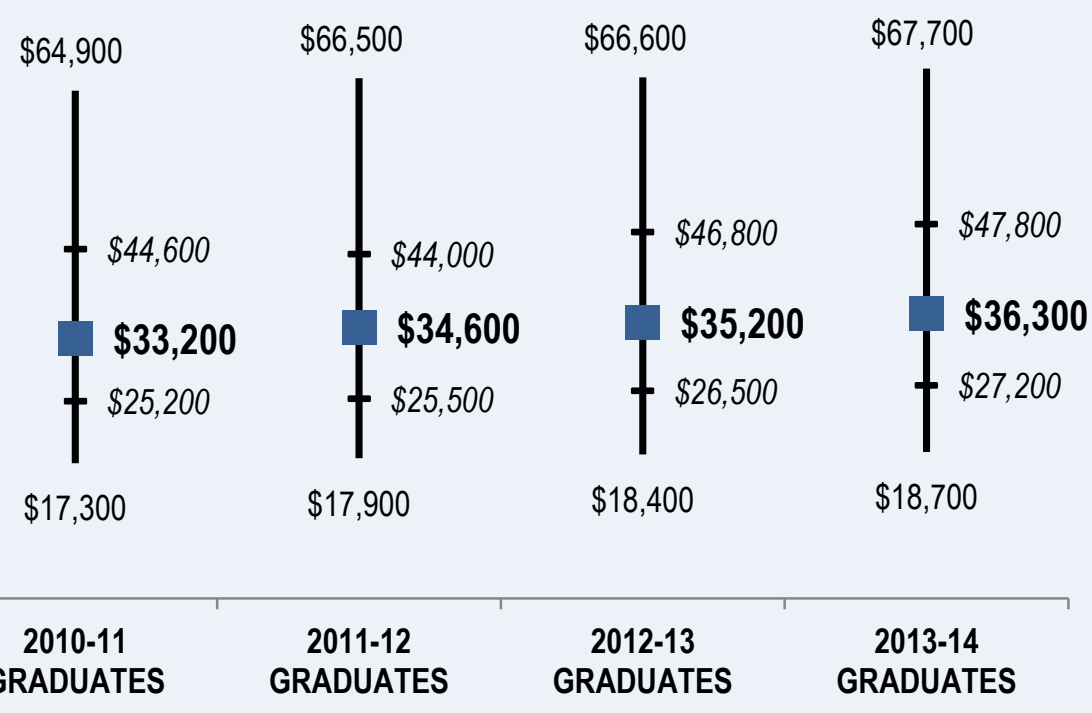

Notes: Percentages are based on the number of recent baccalaureate graduates who are either employed full-time or continuing their education in the U.S. (based on the National Student Clearinghouse data). Full-time employment is based on those who earned more than a full-time (40hrs a week) worker making minimum wage. Due to limitations in the data, the continuing enrollment data includes any enrollment the following year regardless of whether the enrollment was post-baccalaureate or not. BOG staff 'found' $92 \%$ of USF's 2013-14 bachelor's recipients.

See Table 40 within this report for additional information about this metric.

Notes: Wage data is based on Florida's annualized Unemployment Insurance (UI) wage data for those graduates who earned more than a full-time employee making minimum wage in the fiscal quarter a full year after graduation. This UI wage data does not include individuals who are self-employed, employed out of state, employed by the military or federal government, or those without a valid social security number. In 2013-14, these data accounted for $54 \%$ of the total graduating class. This wage data includes graduates who were employed full-time (regardless of their continuing enrollment). Wages are provided for 5th, 25th, 50th, 75th and 95th percentiles. Median wages are identified by bolded values. The interquartile range (shown in italics) represents $50 \%$ of the wage data. Wages rounded to nearest hundreds. 


\section{Performance Based Funding Metrics}

\begin{tabular}{|c|c|c|c|c|}
\hline & & $2012-13$ & 2013-14 & CHANGE \\
\hline \multirow[t]{2}{*}{1} & $\begin{array}{l}\text { Percent Employed Full-time } \\
\text { or Continuing their Education }\end{array}$ & $74.40 \%$ & $75.37 \%$ & $1.0 \%$ pts \\
\hline & & 2012-13 & 2013-14 & CHANGE \\
\hline \multirow[t]{2}{*}{2} & $\begin{array}{l}\text { Median Wages of Bachelor's Graduates } \\
\text { Employed Full-time in Florida }\end{array}$ & $\$ 35,200$ & $\$ 36,300$ & $3.1 \%$ \\
\hline & & $2010-14$ & $2011-15$ & CHANGE \\
\hline \multirow[t]{2}{*}{3} & Cost per Bachelor's Degree & $\$ 25,490$ & $\$ 26,990$ & $5.9 \%$ \\
\hline & & $2008-14$ & $2009-15$ & CHANGE \\
\hline \multirow[t]{2}{*}{4} & $\begin{array}{l}\text { Six-Year Graduation Rate for } \\
\text { First-time-in-College (FTIC) Students }\end{array}$ & $66.10 \%$ & $67.75 \%$ & $1.7 \%$ \\
\hline & & 2013-14 & 2014-15 & CHANGE \\
\hline \multirow[t]{2}{*}{5} & Academic Progress Rate & $85.32 \%$ & $85.05 \%$ & $-0.3 \%$ pts \\
\hline & & 2013-14 & $2014-15$ & CHANGE \\
\hline \multirow[t]{2}{*}{6} & $\begin{array}{l}\text { Bachelor's Degrees Awarded } \\
\text { within Programs of Strategic Emphasis }\end{array}$ & $51.02 \%$ & $54.59 \%$ & $3.6 \%$ pts \\
\hline & & FALL 2013 & FALL 2014 & CHANGE \\
\hline \multirow[t]{2}{*}{7} & University Access Rate & $42.12 \%$ & $41.65 \%$ & $-0.5 \%$ pts \\
\hline & & 2013-14 & 2014-15 & CHANGE \\
\hline \multirow[t]{2}{*}{8} & $\begin{array}{l}\text { Graduate Degrees Awarded } \\
\text { within Programs of Strategic Emphasis }\end{array}$ & $68.95 \%$ & $72.67 \%$ & $3.7 \%$ pts \\
\hline & & 2013-14 & $2014-15$ & CHANGE \\
\hline \multirow[t]{2}{*}{9} & $\begin{array}{l}\text { Board of Governors Choice Metric: } \\
\text { Bachelor's Degrees Without Excess Hours }\end{array}$ & $63.87 \%$ & $65.77 \%$ & $1.9 \%$ pts \\
\hline & & FALL 2012 & FALL 2013 & CHANGE \\
\hline 10 & $\begin{array}{l}\text { Board of Trustees Choice Metric: } \\
\text { Number of post-doctoral appointees }\end{array}$ & 289 & 321 & $11.1 \%$ \\
\hline
\end{tabular}




\section{Key Achievements (2014-2015)}

\section{STUDENT AWARDS/ACHIEVEMENTS}

1. In 2014-15 USF had a record-number of national scholarship winners with 51. This included three Frost Scholars, USF's first ever Gates Cambridge Scholar, two Tillman Scholars and a number of Fulbright, Gates, Gilman, Goldwater, Udal, NSF Graduate Research and Critical Language scholars.

2. USFSP Political Science junior Tyler Lewis interned at the White House during the Spring 2015 semester, joining students from Columbia, Harvard and Cornell, among others.

3. USFSM student Jeanne Ashforth was awarded the Newman Civic Fellowship sponsored by the KPMG Foundation for her commitment to community and service.

\section{FACULTY AWARDS/ACHIEVEMENTS}

1. The American Association for the Advancement of Science named six USF faculty members as fellows - three from the USF College of Marine Science and one each from USF Health, USF College of Engineering and USF College of Arts and Sciences.

2. The USFSP team of Drs. Kathryn and John Arthur continued NSF-funded research to determine the age of a skeleton the team had unearthed in Ethiopia in 2012. They worked closely with geneticists at Cambridge University on a DNA analysis that would lead to a major discovery in the fall of 2015.

3. USFSM Mathematics Professor Joy D'Andrea received the American Mathematical Society award for the Impact of Learning and Teaching Mathematics 2015.

\section{PROGRAM AWARDS/ACHIEVEMENTS}

1. USF's College of Pharmacy earned its first full accreditation from the Accreditation Council for Pharmacy Education; the Morsani College of Medicine was reaccredited by the Liaison Committee for Medical Education.

2. U.S. News and World Report named USF's online graduate engineering, education and business programs among the top 30 in the nation for 2015 - at No. 17, No. 20 and No. 27, respectively.

3. USFSP's Online MBA program was ranked among the nation's top 50 and 2 nd in Florida by U.S. News and World Report.

\section{RESEARCH AWARDS/ACHIEVEMENTS}

1. USF is now ranked No. 25 among public research universities for research expenditures and No. 2 in Florida, according to the National Science Foundation, and No. 41 among all universities, public and private.

2. With 104 patents in 2014 , USF now ranks $10^{\text {th }}$ nationally and $13^{\text {th }}$ among universities worldwide for U.S. Patents, according to the Intellectual Property Owners Association (IPO/NAI).

3. Dr. James McHale of USFSP received notice that he will be awarded an NIH grant for approximately $\$ 3$ million over the next five years for the project titled "Randomized Controlled Trial of Prenatal Coparenting Intervention for African American Fragile Families."

4. The USFSM Center for Partnerships in Arts-Integrated Teaching (PAInT) is supporting Project Elevate, a partnership with Sarasota County Schools and the Any Given Child Sarasota program, which includes the John F. Kennedy Center for the Performing Arts in Washington, D.C., and the Van Wezel Performing Arts Hall in Sarasota 


\section{INSTITUTIONAL AWARDS/ACHIEVEMENTS}

1. The USF System was ranked No. 2 most veteran-friendly university in the country by Military Times and No. 1 by Money Magazine.

2. The USF System was named an Innovation and Economic Prosperity University by the Association of Public and Land-grant Universities (APLU) in recognition of its strong commitment to economic engagement - one of only 18 institutions who received the designation in 2015.

3. USF was recognized as the Most Engaged Campus of the Year by the Florida Campus Compact; the university is one of only 40 public research universities nationwide designated as community engaged by the Carnegie Foundation for the Advancement of Teaching. 


\section{Narrative}

\section{Teaching and Learning}

STRENGTHEN QUALITY AND REPUTATION OF ACADEMIC PROGRAMS AND UNIVERSITIES

The University of South Florida System continues to increase the quality and reputation of its academic programs - evidenced by the record-setting upward trend of its student profile. In just 15 years, the average SAT score of incoming freshmen has improved from 1065 to 1212, and the average high school GPA has increased from 3.49 to 4.04. Incoming ACT scores now stand at an average of 27.

It's equally telling that this year the Morsani College of Medicine had a 24 percent increase in applicants, with 5,000 applicants vying for just 170 slots, and its first-year class of medical students has the highest average MCAT scores in the entire state of Florida.

These kinds of academic gains strengthen USF's eligibility for membership in the Association of American Universities (AAU), heightened excellence within the State University System of Florida and other prestigious national rankings.

\section{INCREASE DEGREE PRODUCTIVITY AND PROGRAM EFFICIENCY}

Maximizing efficiencies and accountability is something the USF System leadership monitors closely as part of the continual data-driven performance review that guides all budget and policy decisions. This strategy has helped us maintain our leadership in the Board of Governors' performance-based funding model, allowing us to reinvest precious resources in areas that directly support student success.

USF is now leading the SUS in baccalaureate and graduate degrees awarded in areas of strategic emphasis for the state. Our six-year graduation rate remains one of the fastest rising among public research universities nationwide. Currently at 67 percent and estimated to go higher, we continue to focus on greater academic support and build a campus environment that supports and celebrates success - a strategy that has allowed us to eliminate the degree completion gap by socioeconomic status and race or ethnicity.

Where possible, we always look to innovative new teaching strategies and online learning opportunities to support student choices and maximize efficiencies. The USF System now offers 91 fully online degrees and certificates at both the undergraduate and graduate levels. These programs not only provide students with options that best meet their needs and schedules, but they also offer skills that provide a competitive advantage to working professionals' continuing education.

Another efficiency strategy is the USF Textbook Affordability Project (TAP), which in the past five years has collectively saved students more than $\$ 1$ million through the use of e-books, expanded course reserve options and open-access textbooks authored by USF faculty. USF is working to expand these options and support faculty members' efforts to author more open-access textbook for the benefit of students at USF and beyond. We are now working with our SUS partners to share best practices and explore cost-sharing opportunities.

USFSP has organized a large and diverse group of academic leaders to plan actions that target activities around improving the quality of entering students, retention, and graduation rates. These efforts have resulted in a proposal to launch a comprehensive first-year experience program titled Compass. Compass is designed to integrate new students into the academic and socio-cultural communities of USFSP. Activities target first-year student needs, success strategies, and peer coaching. 
As a result of efforts like these, the USF System now boasts one of the lowest cost-per-baccalaureatedegree in the SUS. Additionally, USF distributes more financial aid from differential tuition than any other university, and we also invest the highest proportion of state funds in the SUS (74\%) on direct student instruction and research, according to the Board of Governors most recent Expenditure Analysis.

\section{INCREASE THE NUMBER OF DEGREES AWARDED IN S.T.E.M. AND OTHER PROGRAMS OF STRATEGIC EMPHASIS}

In 2014-15, 57\% percent of the USF System's undergraduate degrees were awarded in areas of strategic emphasis, including 23\% percent in STEM. In graduate degrees, $76 \%$ percent of our degrees were in areas of strategic emphasis, including $31 \%$ percent in STEM.

This year USF graduated its first class of College of Pharmacy students and held the first ever commencement ceremony solely for USF Health graduates - a reflection of our commitment to supporting the health workforce in Tampa Bay and indeed across the state of Florida. It is because of this commitment that we have worked so hard to move the Morsani College of Medicine and USF Health Heart Institute to downtown Tampa to best meet the demands of our students, faculty, researchers and the health workforce.

Since attaining separate accreditation in 2011, USF Sarasota-Manatee has added four degree programs recognized by the Board of Governors as programs of Strategic Emphasis. The newest of these is the Bachelor of Science (B.S.) in Biology, which began enrolling students in Fall 2014. USF SarasotaManatee is partnering with Mote Marine Laboratories, a world-renowned marine science laboratory, to deliver the laboratory courses in Mote's facility.

USFSP was also recently granted approval to offer a new Master's of Accountancy program. The MAcc is a 10-course (30 credit hour) graduate program that can be completed in hybrid format (some classes online, some on campus), or 100 percent on campus. The curriculum includes three core classes and seven electives. USFSP established an Institute for Data Analytics and Visualization, which will deliver courses and research on much sought-after topics of big data.

\section{Scholarship, Research and Innovation}

\section{STRENGTHEN QUALITY AND REPUTATION OF SCHOLARSHIP, RESEARCH AND INNOVATION}

Research, scholarship and innovative activity are key differentiators for the USF System. We presently rank 25th in total research expenditures among public universities and 41st among all U.S. universities, public or private, by the National Science Foundation, placing us as the No. 2 academic research engine in Florida.

One of the most exciting developments this year was the naming of USF by the National Science Foundation as an Innovation Corps Site, one of only 36 nationwide. USF will receive nearly $\$ 300,000$ to build, train, and mentor teams of USF faculty and students to become successful entrepreneurs and commercialize their ideas over the next three years. The goal is to launch multiple successful start-up companies at the end of the three-year grant.

USF St. Petersburg was also well represented among the global community of Fulbright scholars, with seven individuals receiving the coveted award to support their work at institutions around the world. 
Additionally, in April 2015, more than 150 students participated in USFSP's Annual Student Research Symposium-more than ever in the 12-year history of the event.

Similarly, USF Sarasota-Manatee appointed a Faculty Coordinator of Research in the spring of 2014 to ensure that the institution leverages opportunities for cross-disciplinary research and actively develops and manages faculty needs and priorities for grants and other resources.

Meanwhile, the USF-grown National Academy of Inventors (NAI) continues to thrive nationwide, now boasting more than 3,000 individual inventor members and 414 NAI Fellows spanning more than 200 academic and research institutions. The state of Florida has 42 elected NAI Fellows among this elite group, representing 10 universities and non-profit research institutes. In 2014, 170 academic inventors from 114 research universities and non-profit research institutes were added to the ranks of NAI Fellows, including 11 Florida inventors from USF, University of Florida (UF), Florida State University (FSU), University of Central Florida (UCF), Moffitt Cancer Center, the Institute for Human \& Machine Cognition (IHMC), and Torrey Pines Institute for Molecular Studies. The 2014 Fellows account for nearly 5,000 issued U.S. patents, bringing the collective patents held by all NAI Fellows to more than 14,000.

USF also founded and is home to the Florida Inventors Hall of Fame, which was recognized by the Florida Senate and inducted its first class of Florida inventors in September 2014, including Thomas Edison and inventors from USF, UF, UCF, and Florida Atlantic University (FAU).

\section{INCREASE RESEARCH AND COMMERCIALIZATION ACTIVITY}

USF's annual research expenditures continue to climb, a key indicator of our booming research productivity. Annual research expenditures now total $\$ 448.6$ million - up from $\$ 145.4$ million 15 years ago. This productivity is further evidenced by the USF System's impressive record in registering patents. The university has ranked among the top 15 universities worldwide for the past 5 years in patenting new inventions - now ranked 13th in the world for U.S. utility patents and10th nationally, with 104 patents registered for 2014 . There are now nearly 60 products on the market that were developed at USF, as well as 12 USF technologies currently in human clinical trials.

The real-world application of our discoveries and technologies shows us how our intellectual power can spark new opportunities. One especially exciting venture has been The Florida Center for Cybersecurity - known as FC2 - which was created just two years ago by the Florida Legislature and Gov. Rick Scott. FC2 this year earned a National Center of Academic Excellence designation from the National Security Agency and Department of Homeland Security. FC2 has forged partnerships with leading national institutions such as J.P. Morgan Chase, which recently provided a $\$ 300,000$ grant to fast-track the training of newly retired military personnel as cybersecurity professionals.

Sponsored through funding from the SUS, faculty from USFSP's Entrepreneurship and Journalism programs partnered with The Greenhouse of the City of St Petersburg, a unit dedicated to supporting and growing local businesses, to establish the capability for "backpack" journalism. Video equipment procured by this funding was used by USFSP Entrepreneurship students to record weekly sessions of "One Million Cups," a City initiative where business pitches are made. The City reports hosting 49 sessions with an estimated overall participation of 3,900 entrepreneurs, corporate representatives, and investors. 
USF Sarasota-Manatee faculty were hard at work in 2014-15 conducting research and innovating curriculum. For instance, John Stewart, Professional \& Technical Communications, created a virtual technical communications lab for online USF Sarasota-Manatee students. This laboratory successfully introduces students to the basics of XML authoring and other related high-end technology. The experience translated into national success when Professor Stewart was invited to present his paper "Implementing an XML Authoring Project in A new Media Course" at the IEEE International Professional Communication Conference at Carnegie Mellon University (October 2014).

\section{INCREASE COLLABORATION AND EXTERNAL SUPPORT FOR RESEARCH ACTIVITY}

The USF System's future is dependent on our success in brokering mutually beneficial partnerships outside of our university community. Of the USF System's total $\$ 440.6$ million in external research funding in 2015, 42\% came from community partnerships, mostly from private or foundation partners. Currently, USF has more than 200 active collaborative agreements in more than 60 countries with more than 170 institutions around the world, laying the foundation for the development of strengthening and enriching international educational and research experiences for both faculty and students.

One recent collaboration has resulted in the selection of USF, in partnership with the Tampa Bay WaVE, as a recipient of a 2014 Regional Innovation Strategies program grant by U.S. Secretary of Commerce Penny Pritzker. USF is among 26 recipients of the $\$ 500,000$ i6 Challenge grant. Matching contributions from public and private community partners raise the total project amount to over $\$ 1$ million.

At USFSP, Dr. James McHale received notice that he will be awarded an NIH grant for approximately $\$ 3$ million over the next five years for the project titled, "Randomized Controlled Trial of Prenatal Coparenting Intervention for African American Fragile Families."

Most USF Sarasota-Manatee faculty members collaborate with non-profit and public organizations from across the Sarasota-Manatee region, including: the Sarasota and Manatee School Districts, Easter Seals, Jewish Federation, and Family Safety Alliance, to name just a few. These collaborative efforts provide opportunities for faculty to conduct research, assist non-profits and public entities, and provide opportunities for students to be involved in research activities, internships, and to identify and connect with local job opportunities.

\section{Community and Business Engagement STRENGTHEN QUALITY AND REPUTATION OF COMMITMENT TO COMMUNITY AND BUSINESS ENGAGEMENT}

The USF System's commitment to community and business engagement has been validated by several external constituencies this past year. First, USF earned the 2015 Community Engagement classification by the Carnegie Foundation for the Advancement of Teaching, which recognizes colleges and universities with an institutional focus on community engagement. USF is one of a small group of public research universities nationwide with very high research activity to be designated as community engaged. Unlike the Carnegie Foundation's other classifications that rely on national data, this is an "elective" classification - institutions participate voluntarily by submitting required materials describing the nature and extent of their engagement with the community, be it local or beyond.

USF was also named an Innovation \& Economic Prosperity University by the Association of Public and Land-grant Universities (APLU), in recognition of its strong commitment to economic engagement - one of 18 universities to receive the recognition this year, a designation held by only 48 universities nationwide, and the second university in Florida to receive the designation. The designation acknowledges universities working with public and private sector partners in their states and regions to 
support economic development through a variety of activities, including innovation and entrepreneurship, technology transfer, talent and workforce development, and community development.

USF is also leading an effort to reenergize the region surrounding the campus as part of the new Tampa Innovation Alliance, engaging neighbors such as Busch Gardens, Moffitt Cancer Center, Florida Hospital, the James A. Haley Veterans' Hospital, and the Museum of Science and Industry (MOSI) in a mutually beneficial economic revitalization. The initiative is now beginning to take shape with a recent $\$ 2$ million investment from Hillsborough County.

USF's close relationship with MOSI can also be seen in a new partnership that unites the two institutions in a number of projects to provide science, technology, engineering, art, math and medicine (STEAMM) education to the Tampa Bay community on a larger scale. The agreement is also designed to motivate and excite K-12 students to pursue post-secondary education in STEAMM disciplines through innovative joint programs, resources and opportunities. Subject matter may include, but is not limited to Biotechnology, Health, Cyber Security, Entrepreneurship, Engineering and Global Sustainability.

Across the Bay, USFSP Regional Chancellor Sophia Wisniewska was named co-chair of St.

Petersburg's new Innovation District, playing a key role in the city's effort to attract attention to our own innovation and research and that of our neighbors, including All Children's/Johns Hopkins Medicine, the St. Petersburg Downtown Partnership, the USF College of Marine Science and the Florida Institute of Technology.

As part of USF Sarasota-Manatee's new 2015-2020 Strategic Plan, "Focus on Quality," developed by faculty and staff in the spring of 2015, USF Sarasota-Manatee formed a plan to build a campus-wide infrastructure to support community engagement. Efforts are under way with the establishment of the Office of Community Engagement and the hiring of a Faculty Coordinator of Community Engagement. The Office is charged with cultivating strategic partnerships with government entities, service clubs, and community organizations.

\section{INCREASE LEVELS OF COMMUNITY AND BUSINESS ENGAGEMENT}

The USF System's commitment to community engagement is highlighted in a number of different ways by each of its three institutions.

At USF in Tampa, nearly 4,000 students enrolled in the nearly 200 service-learning courses, performing 60,000 hours of service to the community which, based upon federal calculations of the value of volunteer work, means they've provided $\$ 1.25$ million dollars of community-engaged work on behalf of local organizations in service-learning classes alone. In addition to benefitting the community, these activities also enhance student success through increased academic performance, graduation rates and career preparation.

Another example of this commitment can be seen at the Muma College of Business, which has a corporate mentorship program that pairs first-generation college students with business leaders to guide them through professional development activities. The result: 100 percent of these students have a job offer at graduation. 
Partnerships with corporate and community leaders continued to be integral to thoughtful growth at USFSP. Among the successes in 2014-15 was a new, state-funded Center for Infant Mental Health with Johns Hopkins/All Children's Hospital. USFSP partnered this year with Duke Energy to install a solar array on the top of the parking garage and, more importantly, will continue to work with Duke to explore the integration of storing solar energy in new battery systems.

At USFSM, Dr. Marie Byrd, Dr. Helene Robinson, Dr. Brianne Reck, and Dr. Pat Wilson of the College of Education and the Center for Partnerships in Arts-Integrated Teaching (PAInT) collaborated with Manatee School District's Early Learning Program and G. D. Rogers Garden Elementary School's principal to design a professional development program. The program was awarded a grant for implementation by the Manatee Community Foundation.

\section{INCREASE COMMUNITY AND BUSINESS WORKFORCE}

Laser-focused on ensuring that graduates are poised for success in today's workforce, the USF System embarked on several new initiatives using performance-based funding to support the local workforce. Among the most visible signs of this new investment is the revamped career resource centers in Tampa, St. Petersburg and Sarasota-Manatee, which has hired several new positions designed to prepare students for today's workforce and expand relationships with local employers. These positions will focus on building additional internships for students and on integrating enhanced career-readiness initiatives into the traditional college experience. Additional funding will be used to hire staff to meet the increased demand to support all students' academic success.

In Spring 2015, USFSP received the final legislative funding (\$12 million) necessary to complete construction of a new building for the Kate Tiedemann College of Business. In Fall 2014, nearly 1,200 undergraduate and graduate students were enrolled in the College. The Kate Tiedemann College of Business continues to offer the USFSP Banking Institute, which provides management training for the C1 Bank Management Associate Program in the bank's new headquarters in downtown St. Petersburg. This corporate partnership entered its fourth successful year of training the new executives.

Another high-profile example of this effort is the new Morsani College of Medicine and USF Health Heart Institute location in downtown Tampa. The downtown site will position the medical school in close proximity to USF Health's primary teaching and clinical affiliate, Tampa General Hospital, as well as its world-class simulation center, the USF Health Center for Advanced Medical Learning and Simulation (CAMLS) and other surrounding facilities. The investment also strengthens the university's presence in downtown Tampa's business district and allows USF Health to simultaneously expand essential educational and research programs at its main campus location. Co-locating the USF Health Heart Institute with the new MCOM building downtown will also enhance recruitment of top cardiovascular researchers, support clinical and translational research opportunities to advance public health, increase MCOM's National Institutes of Health funding levels and improve the rankings of MCOM and USF's partner, TGH. 


\section{Data Tables}

\section{FINANCIAL RESOURCES}

Table 1A. Education and General Revenues

Table 1B. Education and General Expenditures

Table 1C. Funding per Student FTE

Table 1D. Cost per Degree [New]

Table 1E. Other Budget Entities

Table 1F. Voluntary Support of Higher Education

PERSONNEL

Table 2A. Personnel Headcount

\section{ENROLLMENT}

Table 3A. Headcount Enrollment by Student Type

Table 3B. Full-time Equivalent (FTE) Enrollment

Table 3C. Enrollment by Method of Instruction

Table 3D. Headcount Enrollment by Military Status and Student Level

Table 3E. University Access Rate: Undergraduate Enrollment with Pell Grant

\section{UNDERGRADUATE EDUCATION}

Table 4A. Baccalaureate Degree Program Changes in AY 2014-2015

Table 4B. Retention Rates

Table 4C. First-Time-in-College (FTIC) Six-Year Graduation Rates (Full-time only)

Table 4D. FTIC Graduation Rates (Full- and Part-time)

Table 4E. AA Transfers Graduation Rates

Table 4F. Other Transfers Graduation Rates

Table 4G. Baccalaureate Degrees Awarded

Table 4H. Baccalaureate Degrees Awarded in Areas of Strategic Emphasis

Table 4I. Baccalaureate Degrees Awarded to Underrepresented Groups

Table 4J. Baccalaureate Degrees Without Excess Credit Hours

Table 4K. Undergraduate Course Offerings

Table 4L. Faculty Teaching Undergraduates

Table 4M. Student/Faculty Ratio

Table 4N. Licensure/Certification Exam: Nursing

Table 4O. Post-Graduation Metrics

\section{GRADUATE EDUCATION}

Table 5A. Graduate Degree Program Changes in AY 2014-2015

Table 5B. Graduate Degrees Awarded

Table 5C. Graduate Degrees Awarded in Areas of Strategic Emphasis

Table 5D. Licensure/Certification Exams: Graduate Programs

\section{RESEARCH \& ECONOMIC DEVELOPMENT}

Table 6A. Research and Development Expenditures

Table 6B. Centers of Excellence 


\section{Section 1 - Financial Resources}

TABLE 1A. University Education and General Revenues (Not Adjusted for Inflation)

\begin{tabular}{lrrrrr} 
& $\begin{array}{r}\mathbf{2 0 1 1 - 1 2} \\
\text { Actual }\end{array}$ & $\begin{array}{r}\mathbf{2 0 1 2 - 1 3} \\
\text { Actual }\end{array}$ & $\begin{array}{r}\mathbf{2 0 1 3 - 1 4} \\
\text { Actual }\end{array}$ & $\begin{array}{r}\mathbf{2 0 1 4 - 1 5} \\
\text { Actual }\end{array}$ & $\begin{array}{r}\mathbf{2 0 1 5 - 1 6} \\
\text { Estimates }\end{array}$ \\
\hline MAIN OPERATIONS & & & & & \\
\hline Recurring State Funds & $\$ 239,016,278$ & $\$ 230,779,497$ & $\$ 248,172,676$ & $\$ 276,107,424$ & $\$ 269,856,524$ \\
\hline Non-Recurring State Funds & $\$ 2,656,583$ & $-\$ 48,242,853$ & $\$ 4,203,604$ & $\$ 2,066,536$ & $\$ 24,177,973$ \\
\hline Tuition & $\$ 136,448,693$ & $\$ 141,487,748$ & $\$ 148,736,779$ & $\$ 156,109,761$ & $\$ 162,016,366$ \\
\hline Tuition Differential Fee & $\$ 22,361,250$ & $\$ 33,908,713$ & $\$ 33,418,653$ & $\$ 33,242,501$ & $\$ 33,454,344$ \\
\hline Misc. Fees \& Fines & $\$ 3,152,439$ & $\$ 2,810,903$ & $\$ 2,969,679$ & $\$ 3,698,982$ & $\$ 4,838,970$ \\
\hline Phosphate Research TF & $\$ 7,337,035$ & $\$ 0$ & $\$ 0$ & $\$ 0$ & $\$ 0$ \\
\hline Federal Stimulus Funds & $\$ 0$ & $\$ 0$ & $\$ 0$ & $\$ 0$ & $\$ 0$ \\
\hline SUBTOTAL & $\$ 410,972,278$ & $\$ 360,744,008$ & $\$ 437,501,391$ & $\$ 471,225,204$ & $\$ 494,344,177$
\end{tabular}

HEALTH SCIENCE CENTER / MEDICAL SCHOOL

\begin{tabular}{lrrrrr}
\hline Recurring State Funds & $\$ 63,127,971$ & $\$ 65,793,008$ & $\$ 71,529,136$ & $\$ 72,577,386$ & $\$ 72,920,145$ \\
\hline Non-Recurring State Funds & $\$ 250,000$ & $\$ 0$ & $\$ 1,409,562$ & $\$ 2,100,000$ & $\$ 1,000,000$ \\
\hline Tuition & $\$ 41,065,438$ & $\$ 48,203,644$ & $\$ 51,733,993$ & $\$ 47,109,158$ & $\$ 53,751,644$ \\
\hline Tuition Differential Fee & $\$ 1,703,379$ & $\$ 2,956,633$ & $\$ 3,248,580$ & $\$ 3,339,071$ & $\$ 3,542,332$ \\
\hline Misc. Fees \& Fines & $\$ 2,568$ & $\$ 41,978$ & $\$ 83,414$ & $\$ 107,281$ & $\$ 131,800$ \\
\hline Phosphate Research TF & $\$ 0$ & $\$ 0$ & $\$ 0$ & $\$ 0$ & $\$ 0$ \\
\hline Federal Stimulus Funds & $\$ 0$ & $\$ 0$ & $\$ 0$ & $\$ 0$ & $\$ 0$ \\
\hline SUBTOTAL & $\$ 106,149,356$ & $\$ 116,995,263$ & $\$ 128,004,685$ & $\$ 125,232,896$ & $\$ 131,345,921$
\end{tabular}

\section{TOTAL}

$\$ 477,739,271$

$\$ 565,506,076$

$\$ 596,458,100$

$\$ 625,690,098$

Recurring State Funds: include general revenue and lottery education \& general (E\&G) appropriations and any administered funds provided by the state, including annual adjustments of risk management insurance premiums for the estimated year. This does not include technical adjustments or transfers made by universities after the appropriation. Please note: 2013-14 revenues include the non-recurring $\$ 300 \mathrm{M}$ system budget reduction. Sources: SUS Final Amendment Packages were used for actual years; and, the Allocation Summary and Workpapers were used for the estimated year. Non-Recurring State Funds: include general revenue and lottery education \& general appropriations and any administered funds provided by the state. This does not include technical adjustments or transfers made by Universities after the appropriation. Source: non-recurring appropriations section of the annual Allocation Summary and Workpapers that include all other non-recurring budget amendments allocated later in the fiscal year. Note on Performance Funding: the State investment piece of performance funding is reported in the 'Non-Recurring State Funds' and the Institutional investment piece is reported within 'Recurring State Funds'. Tuition: Actual resident \& non-resident tuition revenues collected from students, net of fee waivers. Source: Operating Budget, Report 625 Schedule I-A. Tuition Differential Fee: Actual tuition differential revenues collected from undergraduate students. Source: Operating Budget, Report 625 Schedule I-A. Miscellaneous Fees \& Fines: Other revenue collections include items such as application fees, late registration fees, library fines, miscellaneous revenues. This is the total revenue from Report 625 minus tuition and tuition differential fee revenues. This does not include local fees. Source: Operating Budget, Report 625 - Schedule I-A. Phosphate Research Trust Fund: State appropriation for the Florida Industrial and Phosphate Research Institute at the University of South Florida (for history years through 2012-13); beginning 2013-14 the Phosphate Research Trust Fund is appropriated through Florida Polytechnic University. Other Operating Trust Funds. For UF-IFAS and UF-HSC, actual revenues from the Incidental Trust Funds and Operations \& Maintenance Trust Fund are provided by the University of Florida. Source: Final Amendment Package. Federal Stimulus Funds: Non-recurring American Recovery and Reinvestment Act funds appropriated by the state. Source: SUS Final Amendment Package. This data is not adjusted for inflation. 


\section{Section 1 - Financial Resources (continued)}

TABLE 1B. University Education and General Expenditures (Not Adjusted for Inflation)

\begin{tabular}{lrrrrr} 
& $\mathbf{2 0 1 0 - 1 1}$ & $\mathbf{2 0 1 1 - 1 2}$ & $\mathbf{2 0 1 2 - 1 3}$ & $\mathbf{2 0 1 3 - 1 4}$ & $\mathbf{2 0 1 4 - 1 5}$ \\
\hline MAIN OPERATIONS & & & & & \\
\hline Instruction/Research & $\$ 247,614,259$ & $\$ 237,707,579$ & $\$ 287,236,489$ & $\$ 291,847,040$ & $\$ 306,815,335$ \\
\hline Administration and Support & $\$ 24,095,427$ & $\$ 23,893,443$ & $\$ 32,410,560$ & $\$ 30,296,584$ & $\$ 36,591,191$ \\
\hline PO\&M & $\$ 34,491,862$ & $\$ 35,141,676$ & $\$ 41,615,990$ & $\$ 39,965,797$ & $\$ 44,188,957$ \\
\hline Student Services & $\$ 20,347,800$ & $\$ 18,207,622$ & $\$ 16,781,322$ & $\$ 12,004,895$ & $\$ 26,773,012$ \\
\hline Library/Audio Visual & $\$ 13,010,468$ & $\$ 13,297,996$ & $\$ 10,411,967$ & $\$ 14,004,521$ & $\$ 14,235,047$ \\
\hline Other & $\$ 2,854,224$ & $\$ 6,470,660$ & $\$ 6,957,842$ & $\$ 5,869,392$ & $\$ 7,862,423$ \\
\hline TOTAL & $\$ 342,414,040$ & $\$ 334,718,976$ & $\$ 395,414,170$ & $\$ 393,988,229$ & $\$ \mathbf{4 3 6 , 4 6 5 , 9 6 5}$
\end{tabular}

HEALTH SCIENCE CENTER / MEDICAL SCHOOL

\begin{tabular}{lrrrrr}
\hline Instruction/Research & $\$ 76,521,544$ & $\$ 76,382,108$ & $\$ 95,673,445$ & $\$ 102,295,643$ & $\$ 116,949,551$ \\
\hline Administration and Support & $\$ 6,375,343$ & $\$ 5,076,837$ & $\$ 8,132,708$ & $\$ 6,263,326$ & $\$ 7,116,200$ \\
\hline PO\&M & $\$ 1,373,059$ & $\$ 1,800,847$ & $\$ 7,019,397$ & $\$ 7,391,135$ & $\$ 11,558,700$ \\
\hline Library/Audio Visual & $\$ 2,437,820$ & $\$ 3,043,160$ & $\$ 2,921,295$ & $\$ 2,587,261$ & $\$ 2,961,575$ \\
\hline Teaching Hospital \& Clinics & $\$ 0$ & $\$ 0$ & $\$ 0$ & $\$ 0$ & $\$ 0$ \\
\hline Student Services, and Other & $\$ 1,640$ & $\$ 0$ & $\$ 0$ & $\$ 0$ & $\$ 4,686$ \\
\hline TOTAL & $\$ 86,709,406$ & $\$ 86,302,952$ & $\$ 113,746,845$ & $\$ 118,537,365$ & $\$ 138,590,712$
\end{tabular}

TOTAL $\$ 382,130,676 \quad \$ 374,342,907 \quad \$ 509,161,015 \quad \$ 512,525,594 \quad \$ 575,056,677$

The table reports the actual and estimated amount of expenditures from revenues appropriated by the legislature for each fiscal year. The expenditures are classified by Program Component (e.g., Instruction/Research, PO\&M, Administration, etc...) for activities directly related to instruction, research and public service. The table does not include expenditures classified as non-operating expenditures (e.g., to service asset-related debts), and therefore excludes a small portion of the amount appropriated each year by the legislature. Note*: FY 2012-2013 reflects a change in reporting expenditures from prior years due to the new carry-forward reporting requirement as reflected in the 2013-2014 SUS Operating Budget Reports. Since these expenditures will now include carry-forward expenditures, these data are no longer comparable to the current-year revenues reported in table $1 \mathrm{~A}$, or prior year expenditures in table 1B. This data is not adjusted for inflation.

Instruction \& Research: Includes expenditures for state services related to the instructional delivery system for advanced and professional education. Includes functions such as; all activities related to credit instruction that may be applied toward a postsecondary degree or certificate; non-project research and service performed to maintain professional effectives; individual or project research; academic computing support; academic source or curriculum development. Source: Operating Budget Summary - Expenditures by Program Activity (or Report 645). Administration \& Support Services: Expenditures related to the executive direction and leadership for university operations and those internal management services which assist and support the delivery of academic programs. Source: Operating Budget Summary - Expenditures by Program Activity (or Report 645). PO\&M: Plant Operations \& Maintenance expenditures related to the cleaning and maintenance of existing grounds, the providing of utility services, and the planning and design of future plant expansion and modification. Student Services: Includes resources related to physical, psychological, and social well-being of the student. Includes student service administration, social and cultural development, counseling and career guidance, financial aid, and student admissions and records. Other: includes Institutes and Research Centers, Radio/TV, Museums and Galleries, Intercollegiate Athletics, Academic Infrastructure Support Organizations. Source: Operating Budget Summary - Expenditures by Program Activity (or Report 645). 


\section{Section 1 - Financial Resources (continued)}

TABLE 1C. Funding per Full-Time Equivalent (FTE) Student (Not Adjusted for Inflation)

\begin{tabular}{lrrrrr} 
& $\mathbf{2 0 1 0 - 1 1}$ & $\mathbf{2 0 1 1 - 1 2}$ & $\mathbf{2 0 1 2 - 1 3}$ & $\mathbf{2 0 1 3 - 1 4}$ & $\mathbf{2 0 1 4 - 1 5}$ \\
\hline State Appropriation (GR \& Lottery) & $\$ 7,163$ & $\$ 6,570$ & $\$ 4,996$ & $\$ 7,068$ & $\$ 7,849$ \\
Tuition \& Fees (State-funded Aid) & $\$ 1,372$ & $\$ 1,131$ & $\$ 1,114$ & $\$ 1,115$ & $\$ 1,001$ \\
Tuition \& Fees (from Student) & $\$ 2,580$ & $\$ 3,263$ & $\$ 3,763$ & $\$ 4,070$ & $\$ 4,446$ \\
Other Trust Funds & $\$ 680$ & $\$ 199$ & $\$ 0$ & $\$ 0$ & $\$ 0$ \\
\hline TOTAL & $\$ 11,795$ & $\$ 11,163$ & $\$ 9,873$ & $\mathbf{\$ 1 2 , 2 5 2}$ & $\$ \mathbf{\$ 1 3 , 2 9 6}$
\end{tabular}

Notes: State Appropriations includes General Revenues and Lottery funds that are directly appropriated to the university as reported in Final Amendment Package. This does not include appropriations for special units (e.g., IFAS, Health Science Centers, and Medical Schools). Tuition and Fee revenues include tuition and tuition differential fee and E\&G fees (e.g., application, late registration, and library fees/fines) as reported on the from the Operating Budget 625 reports. Other local fees that do not support E\&G activities are not included here (see Board of Governors Regulation 7.003). To more accurately report the full contribution from the State, this table reports the state-funded financial aid separately from the tuition and fee payments universities receive from students (which may include federal financial aid dollars). The state-funded gift aid includes grants and scholarships as reported by universities to Board during the academic year in the State University Database (SUDS). Other Trust funds (e.g., Federal Stimulus for 2009-10 and 2010-11 only) as reported in Final Amendment Package. Full-time Equivalent enrollment is based on actual FTE, not funded FTE; and, does not include Health-Science Center funds or FTE. This data is based on the standard IPEDS definition of FTE, equal to 30 credit hours for undergraduates and 24 for graduates. This data is not adjusted for inflation.

\section{TABLE 1D. Cost per Degree (Full Expenditures per Bachelor's Degree - Not Adjusted for Inflation)}

\begin{tabular}{llllll} 
& $\mathbf{2 0 0 7 - 1 1}$ & $\mathbf{2 0 0 8 - 1 2}$ & $\mathbf{2 0 0 9 - 1 3}$ & $\mathbf{2 0 1 0 - 1 4}$ & $\mathbf{2 0 1 1 - 1 5}$ \\
\hline TOTAL & $\$ 23,680$ & $\$ 23,280$ & $\$ 24,340$ & $\$ 25,490$ & $\$ 26,990$
\end{tabular}

Notes: Full expenditures include direct instructional, research and public service expenditures and the undergraduate portion of indirect expenditures (e.g., academic administration, academic advising, student services, libraries, university support, and Plant Operations and Maintenance). For each year, the full expenditures were divided by undergraduate fundable student credit hours to calculate the full expenditures per credit hour, and then multiplied by 30 credit hours to represent the annual undergraduate expenditures. The annual undergraduate expenditures for each of the four years was summed to provide an average undergraduate expenditures per (120 credit) degree. Source: State University Database System (SUDS), Expenditure Analysis: Report IV. This data is not adjusted for inflation. 


\section{Section 1 - Financial Resources (continued)}

TABLE 1E. University Other Budget Entities (Not Adjusted for Inflation)

\begin{tabular}{|c|c|c|c|c|c|}
\hline & 2010-11 & 2011-12 & 2012-13 & 2013-14 & 2014-15 \\
\hline \multicolumn{6}{|c|}{ Auxiliary Enterprises } \\
\hline Revenues & $\$ 159,279,590$ & $\$ 166,196,465$ & $\$ 179,066,877$ & $\$ 183,113,399$ & $\$ 204,184,437$ \\
\hline Expenditures & $\$ 128,022,768$ & $\$ 136,665,180$ & $\$ 145,862,330$ & $\$ 155,430,500$ & $\$ 174,301,754$ \\
\hline \multicolumn{6}{|c|}{ Contracts \& Grants } \\
\hline Revenues & $\$ 280,658,090$ & $\$ 253,155,100$ & $\$ 277,146,064$ & $\$ 280,938,042$ & $\$ 281,293,065$ \\
\hline Expenditures & $\$ 305,640,232$ & $\$ 309,631,943$ & $\$ 309,533,722$ & $\$ 322,685,124$ & $\$ 335,670,724$ \\
\hline \multicolumn{6}{|l|}{ Local Funds } \\
\hline Revenues & $\$ 442,397,152$ & $\$ 445,195,358$ & $\$ 447,961,430$ & $\$ 452,561,412$ & $\$ 434,954,904$ \\
\hline Expenditures & $\$ 440,842,216$ & $\$ 444,874,604$ & $\$ 451,386,947$ & $\$ 456,000,627$ & $\$ 435,058,108$ \\
\hline \multicolumn{6}{|c|}{ Faculty Practice Plans } \\
\hline Revenues & $\$ 183,622,430$ & $\$ 194,997,543$ & $\$ 199,933,005$ & $\$ 212,976,074$ & $\$ 229,157,514$ \\
\hline Expenditures & $\$ 182,116,435$ & $\$ 196,288,464$ & $\$ 198,051,785$ & $\$ 126,205,106$ & $\$ 229,678,555$ \\
\hline
\end{tabular}

Notes: Revenues do not include transfers. Expenditures do not include non-operating expenditures. Auxiliary Enterprises are self-supported through fees, payments and charges. Examples include housing, food services, bookstores, parking services, health centers. Contract \& Grants resources are received from federal, state or private sources for the purposes of conducting research and public service activities. Local Funds are associated with student activity (supported by the student activity fee), student financial aid, concessions, intercollegiate athletics, technology fee, green fee, and student life \& services fee. Faculty Practice Plan revenues/receipts are funds generated from faculty practice plan activities. Faculty Practice Plan expenditures include all expenditures relating to the faculty practice plans, including transfers between other funds and/or entities. This may result in double counting in information presented within the annual report. Source: Operating Budget, Report 615. This data is not adjusted for inflation.

TABLE 1F. Voluntary Support of Higher Education (Not Adjusted for Inflation)

\begin{tabular}{cccccc} 
& $\mathbf{2 0 1 0 - 1 1}$ & $\mathbf{2 0 1 1 - 1 2}$ & $\mathbf{2 0 1 2 - 1 3}$ & $\mathbf{2 0 1 3 - 1 4}$ & $\mathbf{2 0 1 4 - 1 5}$ \\
\hline $\begin{array}{c}\text { Endowment Value } \\
(\$ 1000 \mathrm{~s})\end{array}$ & $\$ 344,000$ & $\$ 334,100$ & $\$ 363,924$ & $\$ 417,335$ & $\$ 417,415$ \\
\cline { 1 - 1 } $\begin{array}{c}\text { Gifts Received } \\
(\$ 1000 \mathrm{~s})\end{array}$ & $\$ 81,500$ & $\$ 43,600$ & $\$ 36,520$ & $\$ 37,419$ & $\$ 59,903$ \\
\cline { 1 - 1 } $\begin{array}{c}\text { Percentage of } \\
\text { Alumni Donors }\end{array}$ & $10.0 \%$ & $9.9 \%$ & $9.4 \%$ & $8.9 \%$ & $8.6 \%$ \\
\hline
\end{tabular}

Notes: Endowment value at the end of the fiscal year, as reported in the annual NACUBO Endowment Study. Gifts Received as reported in the Council for Aid to Education's Voluntary Support of Education (VSE) survey in the section entitled "Gift Income Summary," this is the sum of the present value of all gifts (including outright and deferred gifts) received for any purpose and from all sources during the fiscal year, excluding pledges and bequests. (There's a deferred gift calculator at www.cae.org/vse.) The present value of non-cash gifts is defined as the tax deduction to the donor as allowed by the IRS. Percentage of Alumni Donors as reported in the Council for Aid to Education's Voluntary Support of Education (VSE) survey in the section entitled "Additional Details," this is the number of alumni donors divided by the total number of alumni, as of the end of the fiscal year. "Alumni," as defined in this survey, include those holding a degree from the institution as well as those who attended the institution but did not earn a degree. This data is not adjusted for inflation. 


\section{Section 2 - Personnel}

\section{TABLE 2A. Personnel Headcount (in Fall term only)}

\begin{tabular}{lccccc} 
& $\mathbf{2 0 1 0}$ & $\mathbf{2 0 1 1}$ & $\mathbf{2 0 1 2}$ & $\mathbf{2 0 1 3}$ & $\mathbf{2 0 1 4}$ \\
\hline Full-time Employees & & & & & \\
\hline Tenured Faculty & 760 & 755 & 733 & 790 & 785 \\
Tenure-track Faculty & 352 & 387 & 375 & 335 & 329 \\
Non-Tenure Track Faculty & 510 & 501 & 521 & 922 & 695 \\
Instructors Without Faculty Status & 0 & 0 & 0 & 0 & 0 \\
Graduate Assistants/Associates & 0 & 0 & 0 & 0 & 0 \\
Non-Instructional Employees & 4,210 & 4,403 & 4,281 & 5,158 & 5,307 \\
\hline FULL-TIME SUBTOTAL & $\mathbf{5 , 8 3 2}$ & $\mathbf{6 , 0 4 6}$ & $\mathbf{5 , 9 1 0}$ & $\mathbf{7 , 2 0 5}$ & $\mathbf{7 , 1 1 6}$ \\
& & & & & \\
Part-time Employees & 54 & 47 & 56 & 26 & 39 \\
\hline Tenured Faculty & 25 & 21 & 19 & 13 & 18 \\
Tenure-track Faculty & 343 & 381 & 728 & 781 & $761^{*}$ \\
Non-Tenure Track Faculty & 3 & 0 & 0 & 0 & $0^{*}$ \\
Instructors Without Faculty Status & 2,071 & 2,059 & 2,026 & 2,096 & 2,068 \\
Graduate Assistants/Associates & 367 & 211 & 778 & 82 & 73 \\
Non-Instructional Employees & $\mathbf{2 , 8 6 0}$ & $\mathbf{2 , 7 1 9}$ & $\mathbf{3 , 6 0 7}$ & $\mathbf{2 , 9 9 8}$ & $\mathbf{2 , 9 5 9}$ \\
\hline PART-TIME SUBTOTAL & & & & & $\mathbf{1 0 , 0 7 5}$ \\
\hline TOTAL & $\mathbf{8 , 6 9 2}$ & $\mathbf{8 , 7 6 5}$ & $\mathbf{9 , 5 1 7}$ & $\mathbf{1 0 , 2 0 3}$ & $\mathbf{1 0 , 0 7 5}$
\end{tabular}

Note: This table is based on the annual IPEDS Human Resources Survey, and provides full- and part-time medical and non-medical staff by faculty status and primary function/occupational activity. Tenured and Tenure-Track Faculty include those categorized within instruction, research, or public service. Non-Tenure Track Faculty includes adjunct faculty (on annual and less than annual contracts) and faculty on multi-year contracts categorized within instruction, research, or public service. Instructors Without Faculty Status includes postdoctoral research associates, and individuals hired as a staff member primarily to do research on a 3-year contract without tenure eligibility categorized within instruction, research, or public service. Non-Instructional Employees includes all executive, administrative and managerial positions regardless of faculty status; as well as, other support and service positions regardless of faculty status. Note: The universities vary on how they classify adjuncts (some include them as non-tenure track faculty while others do not consider them faculty and report them as instructors without faculty status) and part-time non-instructional employees. 


\section{Section 3 - Enrollment}

\section{TABLE 3A. Headcount Enrollment by Student Type and Level}

\begin{tabular}{lccccc} 
& Fall 2010 & Fall 2011 & Fall 2012 & Fall 2013 & Fall 2014 \\
\hline TOTAL & 47,800 & 47,362 & 47,854 & 48,315 & 48,578
\end{tabular}

UNDERGRADUATE

\begin{tabular}{lccccc}
\hline FTIC (Regular Admit) & 17,549 & 17,043 & 16,930 & 17,059 & 17,174 \\
FTIC (Profile Admit) & 227 & 196 & 173 & 155 & 202 \\
AA Transfers & 10,534 & 11,053 & 11,210 & 11,056 & 10,737 \\
Other Transfers & 7,982 & 7,471 & 7,844 & 7,736 & 6,581 \\
\hline Subtotal & $\mathbf{3 6 , 2 9 2}$ & $\mathbf{3 5 , 7 6 3}$ & $\mathbf{3 6 , 1 5 7}$ & $\mathbf{3 6 , 0 0 6}$ & $\mathbf{3 4 , 6 9 4}$
\end{tabular}

GRADUATE

\begin{tabular}{lccccc}
\hline Master's & 6,522 & 6,395 & 6,481 & 6,806 & 6,950 \\
Research Doctoral & 2,289 & 2,362 & 2,336 & 2,294 & 2,226 \\
Professional Doctoral & 604 & 676 & 905 & 1,220 & 1,379 \\
Dentistry & 0 & 0 & 0 & 0 & 0 \\
Law & 0 & 0 & 0 & 0 & 0 \\
Medicine & 473 & 502 & 549 & 620 & 658 \\
Nursing Practice & 32 & 27 & 30 & 43 & 89 \\
Pharmacy & 0 & 53 & 119 & 225 & 322 \\
Physical Therapist & 99 & 94 & 207 & 332 & 310 \\
Veterinary Medicine & 0 & 0 & 0 & 0 & 0 \\
Other & 0 & 0 & 0 & 0 & 0 \\
\hline Subtotal & $\mathbf{9 , 4 1 5}$ & $\mathbf{9 , 4 3 3}$ & $\mathbf{9 , 7 2 2}$ & $\mathbf{1 0 , 3 2 0}$ & $\mathbf{1 0 , 5 5 5}$
\end{tabular}

UNCLASSIFIED

\begin{tabular}{lccccc}
\hline HS Dual Enrolled & - & - & - & 46 & 16 \\
Other & 2,093 & 2,166 & 1,975 & 1,943 & 3,313 \\
\hline Subtotal & $\mathbf{2 , 0 9 3}$ & $\mathbf{2 , 1 6 6}$ & $\mathbf{1 , 9 7 5}$ & $\mathbf{1 , 9 8 9}$ & $\mathbf{3 , 3 2 9}$
\end{tabular}

Note: This table reports the number of students enrolled at the university by student type categories. The determination for undergraduate, graduate and unclassified is based on the institutional class level values. Unclassified refers to a student who has not yet been formally admitted into a degree program but is enrolled. The student type for undergraduates is based on the Type of Student at Time of Most Recent Admission. The student type for graduates is based on the degree that is sought and the student CIP code. Students classified by the university as post-baccalaureate are counted as "other" unclassified for the purposes of this table. This differs from the methodology used to produce data for the online interactive enrollment tool (on the Board's website) which includes post-bacs as undergraduates regardless of degree sought. 


\section{Section 3 - Enrollment (continued)}

TABLE 3B. Full-Time Equivalent (FTE) Enrollment [State Fundable only]

2012-13

State-

Funded
Actual

StateFunded
2013-14

2014-15

\begin{tabular}{|c|c|c|c|c|c|c|}
\hline & $\begin{array}{l}\text { State- } \\
\text { Funded }\end{array}$ & Actual & $\begin{array}{l}\text { State- } \\
\text { Funded }\end{array}$ & Actual & $\begin{array}{l}\text { State- } \\
\text { Funded }\end{array}$ & Actual \\
\hline \multicolumn{7}{|c|}{ FLORIDA RESIDENTS } \\
\hline Lower-Division & 9,378 & 9,126 & & 8,906 & & 8,718 \\
\hline Upper-Division & 13,361 & 14,688 & & 14,212 & & 13,974 \\
\hline Master's (GRAD I) & 3,680 & 3,447 & & 3,437 & & 3,378 \\
\hline Doctoral (GRAD II) & 854 & 962 & & 945 & & 944 \\
\hline Subtotal & 27,273 & 28,223 & & 27,499 & & 27,014 \\
\hline
\end{tabular}

NON-FLORIDA RESIDENTS

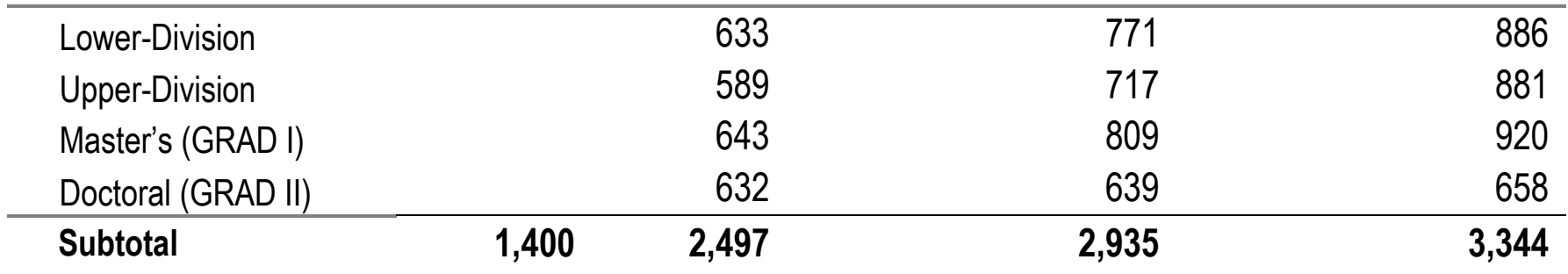

\section{TOTAL FTE}

Lower-Division

Upper-Division

Master's (GRAD I)

9,759

15,278

9,764

13,751

9,677

9,661

9,604

Doctoral (GRAD II)

4,090

4,298

14,928

13,167

14,855

Total (FL Definition)

1,594

860

4,246

3,491

4,298

Total (US Definition)

$\begin{array}{ll}28,673 & 30,720 \\ 38,231 & 40,960\end{array}$

28,673

1,584

842 1,601

Notes: Full-time Equivalent (FTE) student is a measure of instructional effort (and student activity) that is based on the number of credit hours that students enroll by course level. FTE is based on the Florida definition, which divides undergraduate credit hours by 40 and graduate credit hours by 32 (US definition based on Undergraduate FTE = 30 and Graduate FTE = 24 credit hours). In 2013-14, the Florida Legislature chose to no longer separate funded non-resident FTE from funded resident FTE. Funded enrollment as reported in the General Appropriations Act and Board of Governors' Allocation Summary. Actual enrollment only reports 'state-fundable' FTE as reported by Universities to the Board of Governors in the Student Instruction File (SIF). Totals are actual and may not equal sum of reported student levels due to rounding of student level FTE. Total FTE are equal in tables $3 \mathrm{~B}$ and $3 \mathrm{C}$. 


\section{Section 3 - Enrollment (continued)}

\section{TABLE 3C. Full-Time Equivalent (FTE) Enrollment by Method of Instruction}

2010-11 2011-12 2012-13 2013-14 2014-15

\section{TRADITIONAL}

\begin{tabular}{lrrrrr}
\hline Lower-Division & 8,301 & 8,140 & 8,134 & 8,213 & 7,806 \\
Upper-Division & 11,259 & 10,948 & 10,668 & 10,206 & 9,836 \\
Master's (GRAD 1) & 2,888 & 2,863 & 2,796 & 2,967 & 2,979 \\
Doctoral (GRAD 2) & 1,453 & 1,491 & 1,519 & 1,494 & 1,497 \\
\hline TOTAL & $\mathbf{2 3 , 9 0 1}$ & $\mathbf{2 3 , 4 4 2}$ & $\mathbf{2 3 , 1 1 7}$ & $\mathbf{2 2 , 8 8 0}$ & $\mathbf{2 2 , 1 1 9}$
\end{tabular}

HYBRID

\begin{tabular}{lrrrrr} 
Lower-Division & 22 & 48 & 97 & 67 & 69 \\
Upper-Division & 330 & 352 & 390 & 355 & 311 \\
Master's (GRAD 1) & 134 & 147 & 140 & 158 & 129 \\
Doctoral (GRAD 2) & 9 & 5 & 8 & 10 & 8 \\
\hline TOTAL & $\mathbf{4 9 5}$ & $\mathbf{4 8 9}$ & $\mathbf{6 3 5}$ & $\mathbf{5 8 9}$ & $\mathbf{5 1 7}$
\end{tabular}

\section{DISTANCE LEARNING}

\begin{tabular}{lrrrrr} 
Lower-Division & 1,557 & 1,607 & 1,528 & 1,396 & 1,729 \\
Upper-Division & 3,411 & 3,821 & 4,220 & 4,367 & 4,708 \\
Master's (GRAD 1) & 1,108 & 1,034 & 1,154 & 1,121 & 1,190 \\
Doctoral (GRAD 2) & 50 & 62 & 67 & 81 & 97 \\
\hline TOTAL & $\mathbf{6 , 1 2 6}$ & $\mathbf{5 , 0 7 0}$ & $\mathbf{6 , 9 6 9}$ & $\mathbf{6 , 9 6 5}$ & $\mathbf{7 , 7 2 4}$
\end{tabular}

\section{TOTAL}

\begin{tabular}{lrrrrr} 
Lower-Division & 9,880 & 9,795 & 9,759 & 9,677 & 9,604 \\
Upper-Division & 15,000 & 15,121 & 15,278 & 14,928 & 14,855 \\
Master's (GRAD 1) & 4,130 & 4,044 & 4,090 & 4,246 & 4,298 \\
Doctoral (GRAD 2) & 1,512 & 1,558 & 1,594 & 1,584 & 1,601 \\
\hline TOTAL & $\mathbf{3 0 , 5 2 2}$ & $\mathbf{3 0 , 5 1 8}$ & $\mathbf{3 0 , 7 2 0}$ & $\mathbf{3 0 , 4 3 4}$ & $\mathbf{3 0 , 3 5 9}$
\end{tabular}

Note: Full-time Equivalent (FTE) student is a measure of instructional effort (and student activity) that is based on the number of credit hours that students enroll by course level. FTE is based on the Florida definition, which divides undergraduate credit hours by 40 and graduate credit hours by 32. Distance Learning is a course in which at least 80 percent of the direct instruction of the course is delivered using some form of technology when the student and instructor are separated by time or space, or both (per 1009.24(17), F.S.). Hybrid is a course where 50\% to $79 \%$ of the instruction is delivered using some form of technology, when the student and instructor are separated by time or space, or both (per SUDS data element 2052). Traditional (and Technology Enhanced) refers to primarily face to face instruction utilizing some form of technology for delivery of supplemental course materials for no more than $49 \%$ of instruction (per SUDS data element 2052). Totals are actual and may not equal sum of reported student levels due to rounding of student level FTE. Total FTE are equal in tables $3 \mathrm{~B}$ and $3 \mathrm{C}$. 


\section{Section 3 - Enrollment (continued)}

TABLE 3D. Headcount Enrollment by Military Status and Student Level

Fall $2010 \quad$ Fall $2011 \quad$ Fall $2012 \quad$ Fall $2013 \quad$ Fall 2014

\begin{tabular}{lccccc}
\hline MILITARY & \multicolumn{1}{c}{} & & & \\
\hline Unclassified & 29 & 36 & 27 & 29 & 31 \\
Undergraduate & 850 & 933 & 1,014 & 1,025 & 1,079 \\
Master's (GRAD 1) & 148 & 153 & 178 & 187 & 189 \\
Doctoral (GRAD 2) & 18 & 26 & 27 & 18 & 23 \\
\hline Subtotal & $\mathbf{1 , 0 4 5}$ & $\mathbf{1 , 1 4 8}$ & $\mathbf{1 , 2 4 6}$ & $\mathbf{1 , 2 5 9}$ & $\mathbf{1 , 3 2 2}$ \\
DEPENDENTS & & & & & \\
\hline Unclassified & 3 & 1 & 5 & 1 & 2 \\
Undergraduate & 168 & 174 & 190 & 198 & 199 \\
Master's (GRAD 1) & 14 & 14 & 15 & 20 & 16 \\
Doctoral (GRAD 2) & & & 1 & 1 & 0 \\
\hline Subtotal & 185 & 189 & $\mathbf{2 1 1}$ & $\mathbf{2 2 0}$ & $\mathbf{2 1 7}$ \\
NON-MILITARY & & & & & \\
\hline Unclassified & 2,061 & 2,128 & 1,942 & 1,953 & 2,182 \\
Undergraduate & 35,274 & 34,657 & 34,954 & 34,789 & 34,530 \\
Master's (GRAD 1) & 6,804 & 6,755 & 6,937 & 7,434 & 7,712 \\
Doctoral (GRAD 2) & 2,431 & 2,485 & 2,564 & 2,660 & 2,615 \\
\hline Subtotal & 46,570 & 46,025 & 46,397 & 46,836 & $\mathbf{4 7 , 0 3 9}$ \\
\hline TOTAL & $\mathbf{4 7 , 8 0 0}$ & $\mathbf{4 7 , 3 6 2}$ & $\mathbf{4 7 , 8 5 4}$ & $\mathbf{4 8 , 3 1 5}$ & $\mathbf{4 8 , 5 7 8}$ \\
\hline
\end{tabular}

Note: This table provides trend data on the number of students enrolled based on their military status. Military includes students who were classified as Active Duty, Veterans, National Guard, or Reservist. Eligible Dependents includes students who were classified as eligible dependents (dependents who received veteran's benefits). Non-Military includes all other students.

\section{TABLE 3E. University Access Rate (Undergraduate Enrollment with Pell Grant)}

\begin{tabular}{lccccc} 
& Fall 2010 & Fall 2011 & Fall 2012 & Fall 2013 & Fall 2014 \\
\hline Pell Grant Recipients & 13,961 & 14,818 & 14,884 & 14,754 & 14,371 \\
\hline Percent with Pell Grant & $\mathbf{3 8 . 9 4 \%}$ & $\mathbf{4 2 . 0 9 \%}$ & $\mathbf{4 2 . 0 0 \%}$ & $\mathbf{4 2 . 1 2} \%$ & $\mathbf{4 1 . 6 5 \%}$
\end{tabular}

Note: This table reports the University's Access Rate, which is a measure of the percentage of undergraduate students who have received a federal Pell grant award during a given Fall term. The top row reports the number of students who received a Pell Grant award. The bottom row provides the percentage of eligible students that received a Pell Grant award. This metric is included in the Board of Governors Performance Based Funding Model - for more information see: http://www.flbog.edu/about/budget/performance_funding.php. 


\section{Section 4 - Undergraduate Education}

\section{TABLE 4A. Baccalaureate Degree Program Changes in AY 2014-15}

\begin{tabular}{|c|c|c|c|c|c|}
\hline Title of Program & $\begin{array}{c}\text { Six-digit } \\
\text { CIP } \\
\text { Code }\end{array}$ & $\begin{array}{c}\text { Degree } \\
\text { Level }\end{array}$ & $\begin{array}{l}\text { Date of } \\
\text { UBOT } \\
\text { Action }\end{array}$ & $\begin{array}{l}\text { Starting } \\
\text { or Ending } \\
\text { Term }\end{array}$ & Comments \\
\hline \multicolumn{6}{|l|}{ New Programs } \\
\hline \multicolumn{6}{|l|}{ None } \\
\hline & & & & & \\
\hline \multicolumn{6}{|l|}{ Terminated Programs } \\
\hline Athletic Training & 51.0913 & Bachelors & 6/5/2014 & FALL 2014 & \\
\hline \multicolumn{6}{|c|}{ Programs Suspended for New Enrollments } \\
\hline Information Science/Studies & 11.0401 & Bachelors & & FALL 2010 & \\
\hline & & & & & \\
\hline \multicolumn{6}{|c|}{ New Programs Considered By University But Not Approved } \\
\hline None & & & & & \\
\hline
\end{tabular}

Note: This table does not include new majors or concentrations added under an existing degree program CIP Code. This table reports the new and terminated program changes based on Board action dates between May 5, 2014 and May 4, 2015.

New Programs are proposed new degree programs that have been completely through the approval process at the university and, if appropriate, the Board of Governors. Does not include new majors or concentrations added under an existing degree program CIP Code.

Terminated Programs are degree programs for which the entire CIP Code has been terminated and removed from the university's inventory of degree programs. Does not include majors or concentrations terminated under an existing degree program CIP Code if the code is to remain active on the academic degree inventory.

Programs Suspended for New Enrollments are degree programs for which enrollments have been temporarily suspended for the entire CIP Code, but the program CIP Code has not been terminated. Does not include majors or concentrations suspended under an existing degree program CIP Code if the code is to remain active on the academic degree inventory and new enrollments in any active major will be reported. Programs included in this list may have been suspended for new enrollments sometime in the past and have continued to be suspended at least one term of this academic year.

New Programs Considered by University But Not Approved includes any programs considered by the university board of trustees, or any committee of the board, but not approved for implementation. Also include any programs that were returned prior to board consideration by the university administration for additional development, significant revisions, or re-conceptualization; regardless of whether the proposal was eventually taken to the university board for approval. Count the returns once per program, not multiple times the proposal was returned for revisions, unless there is a total re-conceptualization that brings forward a substantially different program in a different CIP Code. 


\section{Section 4 - Undergraduate Education (continued)}

\section{TABLE 4B. Full-time, First-Time-in-College (FTIC) Retention Rates}

\section{Retained in the Second Fall Term at Same University}

\begin{tabular}{cccccc} 
& $\mathbf{2 0 1 0 - 1 1}$ & $\mathbf{2 0 1 1 - 1 2}$ & $\mathbf{2 0 1 2 - 1 3}$ & $\mathbf{2 0 1 3 - 1 4}$ & $\mathbf{2 0 1 4 - 1 5}$ \\
\hline Cohort Size & 4,951 & 4,027 & 4,508 & 4,490 & 4,650 \\
$\begin{array}{c}\text { \% Retained } \\
\text { with Any GPA }\end{array}$ & $85 \%$ & $86 \%$ & $87 \%$ & $87 \%$ & $88 \%$ \\
\hline $\begin{array}{c}\text { \% Retained } \\
\text { with GPA 2.0 or higher }\end{array}$ & $81.26 \%$ & $83.76 \%$ & $84.52 \%$ & $85.32 \%$ & $85.05 \%$
\end{tabular}

Notes: Cohorts are based on undergraduate students who enter the institution in the Fall term (or Summer term and continue into the Fall term). Percent Retained with Any GPA is based on student enrollment in the Fall term following their first year. Percent Retained with GPA Above 2.0 is based on student enrollment in the Fall term following their first years for those students with a GPA of 2.0 or higher at the end of their first year (Fall, Spring, Summer). The most recent year of Retention data is based on preliminary data (SIFP file) that is comparable to the final data (SIF file) but may be revised in the following years based on changes in student cohorts.

\section{TABLE 4C. Full-time, First-Time-in-College (FTIC) Six-Year Graduation Rates}

\begin{tabular}{cccccc} 
Term of Entry & $\mathbf{2 0 0 5 - 1 1}$ & $\mathbf{2 0 0 6 - 1 2}$ & $\mathbf{2 0 0 7 - 1 3}$ & $\mathbf{2 0 0 8 - 1 4}$ & $\mathbf{2 0 0 9 - 1 5}$ \\
\hline Cohort Size & 4,101 & 4,271 & 3,980 & 4,259 & 4,241 \\
\hline$\%$ Graduated & $53 \%$ & $57 \%$ & $64 \%$ & $67 \%$ & $68 \%$ \\
\hline \% Still Enrolled & $9 \%$ & $9 \%$ & $7 \%$ & $6 \%$ & $5 \%$ \\
\hline \% Success Rate & $62 \%$ & $66 \%$ & $71 \%$ & $72 \%$ & $73 \%$
\end{tabular}

Notes: Cohorts are based on FTIC undergraduate students who enter the institution in the Fall term (or Summer term and continue into the Fall term). Percent Graduated reports the percent of FTICs who graduated from the same institution within six years. This metric does not include students who enrolled as part-time students (in their first year), or who transfer into the institution. This metric complies with the requirements of the federal Student Right to Know Act that requires institutions to report the completion status at $150 \%$ of normal time (or six years). Success Rate measures the percentage of an initial cohort of students who have either graduated or are still enrolled at the same university. This data should match the IPEDS Graduation Rate Survey data that is due in late February. 


\section{Section 4 - Undergraduate Education (continued)}

TABLE 4D. Graduation Rates for First-Time-in-College (FTIC) Students (includes Full- and Part-time students)

\begin{tabular}{lccccc}
$\mathbf{4 - \text { Year Rates }}$ & $\mathbf{2 0 0 7 - 1 1}$ & $\mathbf{2 0 0 8 - 1 2}$ & $\mathbf{2 0 0 9 - 1 3}$ & $\mathbf{2 0 1 0 - 1 4}$ & $\mathbf{2 0 1 1 - 1 5}$ \\
\hline Cohort Size & 4,181 & 4,436 & 4,326 & 4,996 & 4,066 \\
Same University & $35 \%$ & $37 \%$ & $42 \%$ & $43 \%$ & $48 \%$ \\
\hline Other University in SUS & $1 \%$ & $1 \%$ & $2 \%$ & $2 \%$ & $2 \%$ \\
\hline Total from System & $36 \%$ & $39 \%$ & $43 \%$ & $45 \%$ & $50 \%$
\end{tabular}

\begin{tabular}{lccccc}
$\mathbf{6}$ - Year Rates & $\mathbf{2 0 0 5 - 1 1}$ & $\mathbf{2 0 0 6 - 1 2}$ & $\mathbf{2 0 0 7 - 1 3}$ & $\mathbf{2 0 0 8 - 1 4}$ & $\mathbf{2 0 0 9 - 1 5}$ \\
\hline Cohort Size & 4,424 & 4,468 & 4,181 & 4,436 & 4,326 \\
Same University & $51.72 \%$ & $56.49 \%$ & $63.21 \%$ & $66.10 \%$ & $67.75 \%$ \\
\hline Other University in SUS & $4 \%$ & $4 \%$ & $3 \%$ & $4 \%$ & $4 \%$ \\
\hline Total from System & $56 \%$ & $60 \%$ & $67 \%$ & $70 \%$ & $72 \%$
\end{tabular}

Notes: Cohorts are based on undergraduate students who enter the institution in the Fall term (or Summer term and continue into the Fall term). First-timein-college (FTIC) cohort is defined as undergraduates entering in fall term (or summer continuing to fall) with fewer than 12 hours earned after high school graduation. The initial cohorts can be revised to remove students, who have allowable exclusions as defined by IPEDS, from the cohort. FTIC students who are enrolled in advanced graduate degree programs that do not award a Bachelor's degree are removed from the cohorts.

Graduates are students in the cohort who have graduated by the summer term in their fourth or sixth year. Degree data often includes 'late degrees' which are degrees that were awarded in a previous term, but reported to SUDS later; so, the most recent year of data in this table only provides preliminary graduation rate data that may change with the addition of "late degrees". Late degrees reported in conjunction with the IPEDS Graduation Rate Survey due in mid-February will be reflected in the following year.

Same University provides graduation rates for students in the cohort who graduated from the same institution.

Other University in SUS provides graduation rates for students in the cohort who graduated from a different State University System of Florida institution. These data do not report students in the cohort who did not graduate from the SUS, but did graduate from another institution outside the State University System of Florida. 


\section{Section 4 - Undergraduate Education (continued)}

\section{TABLE 4E. Graduation Rates for AA Transfer Students from Florida College System}

\begin{tabular}{cccccc} 
Two - Year Rates & $\mathbf{2 0 0 9 - 1 1}$ & $\mathbf{2 0 1 0 - 1 2}$ & $\mathbf{2 0 1 1 - 1 3}$ & $\mathbf{2 0 1 2 - 1 4}$ & $\mathbf{2 0 1 3 - 1 5}$ \\
\hline Cohort Size & 2,333 & 2,484 & 2,609 & 2,527 & 2,558 \\
Same University & $29 \%$ & $28 \%$ & $28 \%$ & $29 \%$ & $28 \%$
\end{tabular}

\begin{tabular}{cccccc} 
Four - Year Rates & $\mathbf{2 0 0 7 - 1 1}$ & $\mathbf{2 0 0 8 - 1 2}$ & $\mathbf{2 0 0 9 - 1 3}$ & $\mathbf{2 0 1 0 - 1 4}$ & $\mathbf{2 0 1 1 - 1 5}$ \\
\hline Cohort Size & 2,216 & 2,536 & 2,333 & 2,484 & 2,609 \\
Same University & $64 \%$ & $66 \%$ & $69 \%$ & $67 \%$ & $67 \%$
\end{tabular}

Notes: AA Transfer cohort is defined as undergraduates entering in the fall term (or summer continuing to fall) and having earned an AA degree from an institution in the Florida College System. For comparability with FTIC cohorts, AA Transfer cohorts are based on undergraduate students who enter the institution in the Fall term (or Summer term and continue into the Fall term) and graduate from the same institution within two or four years.

TABLE 4F. Graduation Rates for Other Transfer Students

\begin{tabular}{cccccc}
$\mathbf{5 - \text { Year Rates }}$ & $\mathbf{2 0 0 6 - 1 1}$ & $\mathbf{2 0 0 7 - 1 2}$ & $\mathbf{2 0 0 8 - 1 3}$ & $\mathbf{2 0 0 9 - 1 4}$ & $\mathbf{2 0 1 0 - 1 5}$ \\
\hline Cohort Size & 2,592 & 2,842 & 2,257 & 2,654 & 2,502 \\
Same University & $60 \%$ & $60 \%$ & $65 \%$ & $63 \%$ & $65 \%$
\end{tabular}

Notes: Other Transfer Students includes undergraduate students that transfer into a university who are not FTICs or AA Transfers. Cohorts are based on undergraduate students who enter the institution in the Fall term (or Summer term and continue into the Fall term) and graduate from the same institution within five years. 


\section{Section 4 - Undergraduate Education (continued)}

TABLE 4G. Baccalaureate Degrees Awarded

\begin{tabular}{lccccc} 
& $\mathbf{2 0 1 0 - 1 1}$ & $\mathbf{2 0 1 1 - 1 2}$ & $\mathbf{2 0 1 2 - 1 3}$ & $\mathbf{2 0 1 3 - 1 4}$ & $\mathbf{2 0 1 4 - 1 5}$ \\
\hline First Majors & 8,190 & 8,827 & 8,999 & 9,390 & 9,290 \\
Second Majors & 147 & 210 & 198 & 213 & 194 \\
\hline TOTAL & $\mathbf{8 , 3 3 7}$ & $\mathbf{9 , 0 3 7}$ & $\mathbf{9 , 1 9 7}$ & $\mathbf{9 , 6 0 3}$ & $\mathbf{9 , 4 8 4}$
\end{tabular}

Note: This table reports the number of degrees awarded by academic year. First Majors include the most common scenario of one student earning one degree in one Classification of Instructional Programs (CIP) code. In those cases where a student earns a baccalaureate degree under two different degree CIPs, a distinction is made between "dual degrees" and "dual majors." Also included in first majors are "dual degrees" which are counted as separate degrees (e.g., counted twice). In these cases, both degree CIPs receive a "degree fraction" of 1.0. Second Majors include all dual/second majors (e.g., degree CIP receive a degree fraction that is less than 1). The calculation of degree fractions is made according to each institution's criteria. The calculation for the number of second majors rounds each degree CIP's fraction of a degree up to 1 and then sums the total. Second Majors are typically used when providing degree information by discipline/CIP, to better conveys the number of graduates who have specific skill sets associated with each discipline.

\section{TABLE 4H. Baccalaureate Degrees in Programs of Strategic Emphasis (PSE)} [Includes Second Majors]

\begin{tabular}{lccccc} 
& $\mathbf{2 0 1 0 - 1 1}$ & $\mathbf{2 0 1 1 - 1 2}$ & $\mathbf{2 0 1 2 - 1 3}$ & $\mathbf{2 0 1 3 - 1 4}$ & $\mathbf{2 0 1 4 - 1 5}$ \\
\hline STEM & 1,635 & 1,897 & 2,071 & 2,064 & 2,055 \\
\hline HEALTH & 446 & 708 & 895 & 1,158 & 1,596 \\
\hline GLOBALIZATION & 243 & 284 & 249 & 289 & 268 \\
\hline EDUCATION & 753 & 689 & 643 & 641 & 475 \\
\hline GAP ANALYSIS & 743 & 787 & 699 & 747 & 783 \\
\hline SUBTOTAL & $\mathbf{3 , 8 2 0}$ & $\mathbf{4 , 3 6 5}$ & $\mathbf{4 , 5 5 7}$ & $\mathbf{4 , 8 9 9}$ & $\mathbf{5 , 1 7 7}$ \\
\hline PSE PERCENT OF TOTAL & $\mathbf{4 5 . 8 2 \%}$ & $\mathbf{4 8 . 3 0 \%}$ & $\mathbf{4 9 . 5 5 \%}$ & $\mathbf{5 1 . 0 2 \%}$ & $\mathbf{5 4 . 5 9 \%}$
\end{tabular}

Notes: This is a count of baccalaureate majors for specific Programs of Strategic Emphasis, as determined by the Board of Governors staff with consultation with business and industry groups and input from universities. This is a count of baccalaureate degrees awarded within specific Programs of Strategic Emphasis, as determined by the Board of Governors staff with consultation with business and industry groups and input from universities - for more information see: http://www.flbog.edu/pressroom/strategic emphasis/. The Board of Governors revised the list of Programs of Strategic Emphasis in November 2013, and the new categories were applied to the historical degrees. A student who has multiple majors in the subset of targeted Classification of Instruction Program codes will be counted twice (i.e., double-majors are included). 


\section{Section 4 - Undergraduate Education (continued)}

\section{TABLE 4I. Baccalaureate Degrees Awarded to Underrepresented Groups}

2010-11 2011-12 2012-13 2013-14 2014-15

Non-Hispanic Black

$\begin{array}{llllll}\text { Number of Degrees } & 921 & 916 & 972 & 945 & 977 \\ \text { Percentage of Degrees } & 12 \% & 11 \% & 11 \% & 10 \% & 11 \%\end{array}$

Hispanic

$\begin{array}{lccccc}\text { Number of Degrees } & 1,140 & 1,390 & 1,433 & 1,645 & 1,728 \\ \text { Percentage of Degrees } & 14 \% & 16 \% & 16 \% & 18 \% & 19 \%\end{array}$

Pell-Grant Recipients

$\begin{array}{lccccc}\text { Number of Degrees } & 3,625 & 4,476 & 4,764 & 5,102 & 5,085 \\ \text { Percentage of Degrees } & 46 \% & 50 \% & 54 \% & 55 \% & 56 \%\end{array}$

Note: Non-Hispanic Black and Hispanic do not include students classified as Non-Resident Alien or students with a missing race code. Students who earn two distinct degrees in the same term are counted twice - whether their degrees are from the same six-digit CIP code or different CIP codes. Students who earn only one degree are counted once - even if they completed multiple majors or tracks. Percentage of Degrees is based on the number of baccalaureate degrees awarded to non-Hispanic Black and Hispanic students divided by the total degrees awarded - excluding those awarded to non-resident aliens and unreported.

Pell-Grant recipients are defined as those students who have received a Pell grant from any SUS Institution within six years of graduation - excluding those awarded to non-resident aliens, who are only eligible for Pell grants in special circumstances. Percentage of Degrees is based on the number of baccalaureate degrees awarded to Pell recipients, as shown above, divided by the total degrees awarded - excluding those awarded to non-resident aliens.

Notes on Trends: In 2007, the US Department of Education re-classified the taxonomy for self-reported race/ethnicity categories and allowed universities a two-year phase-in process before all institutions were required to report based on the new categories for the 2011-12 academic year. This reclassification will impact trends. 


\section{Section 4 - Undergraduate Education (continued)}

\section{TABLE 4J. Baccalaureate Degrees Without Excess Credit Hours}

\begin{tabular}{lccccc} 
& $\mathbf{2 0 1 0 - 1 1}$ & $\mathbf{2 0 1 1 - 1 2}$ & $\mathbf{2 0 1 2 - 1 3}$ & $\mathbf{2 0 1 3 - 1 4}$ & $\mathbf{2 0 1 4 - 1 5}$ \\
\hline FTIC & $50 \%$ & $57 \%$ & $54 \%$ & $61 \%$ & $65 \%$ \\
\hline AA Transfers & $60 \%$ & $60 \%$ & $68 \%$ & $72 \%$ & $74 \%$ \\
\hline Other Transfers & $49 \%$ & $40 \%$ & $52 \%$ & $58 \%$ & $58 \%$ \\
\hline TOTAL & $\mathbf{5 3} \%$ & $\mathbf{5 3} \%$ & $\mathbf{5 8 . 2 0} \%$ & $\mathbf{6 3 . 8 7} \%$ & $\mathbf{6 5 . 7 7 \%}$
\end{tabular}

Notes: This table is based on statute 1009.286 (see link), and excludes certain types of student credits (e.g., accelerated mechanisms, remedial coursework, non-native credit hours that are not used toward the degree, non-native credit hours from failed, incomplete, withdrawn, or repeated courses, credit hours from internship programs, credit hours up to 10 foreign language credit hours for transfer students in Florida, and credit hours earned in military science courses that are part of the Reserve Officers' Training Corps (ROTC) program). This metric is not the same as the Excess Hours Surcharge, which has multiple cohorts with varying fee rates. This table reports the percentage of baccalaureate degrees awarded within $110 \%$ of the catalog hours required for a degree based on the Board of Governors Academic Program Inventory. This calculation is based on Hours To Degree data submitted by universities to the Board of Governors and excludes recent graduates who have already earned a baccalaureate degree. Note*: Improvements were made to data collection process beginning with 2012-13 data to better account for high school dual enrolled credits that are exempt from the excess hour calculation. Also, 2012-13 data marked a slight methodological change in how the data is calculated. Each CIP code's required number of 'catalog hours' was switched to the officially approved hours as reported within the Board of Governors' Academic Program Inventory - instead of the catalog hours reported by the university on the HTD files.

\section{TABLE 4K. Undergraduate Course Offerings}

\begin{tabular}{cccccc} 
& Fall 2010 & Fall 2011 & Fall 2012 & Fall 2013 & Fall 2014 \\
\cline { 2 - 4 } & 3,004 & 3,037 & 3,031 & 2,963 & 2,968
\end{tabular}

\section{Percentage of Undergraduate Course Sections by Class Size}

\begin{tabular}{lccccc}
\hline Fewer than 30 Students & $56 \%$ & $59 \%$ & $59 \%$ & $58 \%$ & $62 \%$ \\
\hline 30 to 49 Students & $29 \%$ & $27 \%$ & $26 \%$ & $28 \%$ & $24 \%$ \\
\hline 50 to 99 Students & $12 \%$ & $11 \%$ & $11 \%$ & $10 \%$ & $10 \%$ \\
\hline 100 or More Students & $3 \%$ & $3 \%$ & $3 \%$ & $4 \%$ & $4 \%$
\end{tabular}

Notes: This data is based on Common Data Set (CDS) definitions. According to CDS, a "class section is an organized course offered for credit, identified by discipline and number, meeting at a stated time or times in a classroom or similar setting, and not a subsection such as a laboratory or discussion session. Undergraduate class sections are defined as any sections in which at least one degree-seeking undergraduate student is enrolled for credit. Exclude distance learning classes and noncredit classes and individual instruction such as dissertation or thesis research, music instruction, or one-to-one readings. Exclude students in independent study, co-operative programs, internships, foreign language taped tutor sessions, practicums, and all students in one-on-one classes. 


\section{Section 4 - Undergraduate Education (continued)}

TABLE 4L. Percentage of Undergraduate Credit Hours Taught by Instructor Type

\begin{tabular}{lccccc} 
& $\mathbf{2 0 1 0 - 1 1}$ & $\mathbf{2 0 1 1 - 1 2}$ & $\mathbf{2 0 1 2 - 1 3}$ & $\mathbf{2 0 1 3 - 1 4}$ & $\mathbf{2 0 1 4 - 1 5}$ \\
\hline Faculty & $66 \%$ & $68 \%$ & $66 \%$ & $67 \%$ & $65 \%$ \\
\hline Adjunct Faculty & $19 \%$ & $17 \%$ & $19 \%$ & $18 \%$ & $20 \%$ \\
\hline Graduate Students & $14 \%$ & $15 \%$ & $14 \%$ & $14 \%$ & $13 \%$ \\
\hline Other Instructors & $1 \%$ & $1 \%$ & $1 \%$ & $1 \%$ & $3 \%$ \\
\hline
\end{tabular}

Note: The total number of undergraduate state fundable credit hours taught will be divided by the undergraduate credit hours taught by each instructor type to create a distribution of the percentage taught by each instructor type. Four instructor types are defined as faculty (pay plans 01,02 , and 22), OPS faculty (pay plan 06), graduate student instructors (pay plan 05), and others (all other pay plans). If a course has more than one instructor, then the university's reported allocation of section effort will determine the allocation of the course's total credit hours to each instructor. The definition of faculty varies for Tables $4 \mathrm{~L}, 4 \mathrm{M}$ and $4 \mathrm{~N}$. For Faculty Teaching Undergraduates, the definition of faculty is based on pay plans 01,02 , and 22.

\section{TABLE 4M. Student/Faculty Ratio}

\begin{tabular}{cccccc} 
& Fall 2010 & Fall 2011 & Fall 2012 & Fall 2013 & Fall 2014 \\
\hline Ratio & 24 & 26 & 24 & 24 & 22
\end{tabular}

Note: This data is based on Common Data Set (CDS) definitions. This is the Fall ratio of full-time equivalent students (full-time plus $1 / 3$ part time) to full-time equivalent instructional faculty (full time plus $1 / 3$ part time). The ratio calculations exclude both faculty and students in stand-alone graduate or professional programs such as medicine, law, veterinary, dentistry, social work, business, or public health in which faculty teach virtually only graduate-level students. Undergraduate or graduate student teaching assistants are not counted as faculty.

\section{TABLE 4N. Professional Licensure/Certification Exams for Undergraduates}

\begin{tabular}{lccccc} 
Nursing: National Council Licensure Examination for Registered Nurses & & \\
& $\mathbf{2 0 1 0}$ & $\mathbf{2 0 1 1}$ & $\mathbf{2 0 1 2}$ & $\mathbf{2 0 1 3}$ & $\mathbf{2 0 1 4}$ \\
\hline Examinees & 169 & 210 & 184 & 186 & 189 \\
First-time Pass Rate & $96 \%$ & $95 \%$ & $93 \%$ & $91 \%$ & $86 \%$ \\
National Benchmark & $89 \%$ & $89 \%$ & $92 \%$ & $85 \%$ & $85 \%$
\end{tabular}

Note: Pass rate for first-time examinees for the National Council Licensure Examination for Registered Nurses (NCLEX-RN) are based on the performance of graduates of baccalaureate nursing programs. National benchmark data is based on Jan-Dec NCLEX-RN results for first-time examinees from students in US-educated baccalaureate degree programs as published by the National Council of State Boards of Nursing. 


\section{Section 4 - Undergraduate Education (continued)}

\section{TABLE 40. Post-Graduation Metrics}

\section{Percent of Bachelor's Graduates Employed Full-time or Continuing their Education, One Year After Graduation}

\begin{tabular}{lcccc} 
& $\mathbf{2 0 1 0 - 1 1}$ & $\mathbf{2 0 1 1 - 1 2}$ & $\mathbf{2 0 1 2 - 1 3}$ & $\mathbf{2 0 1 3 - 1 4}$ \\
\hline Enrolled or Employed (Full-time) & $69.14 \%$ & $70.44 \%$ & $74.40 \%$ & $75.37 \%$ \\
Enrolled or Employed (Earned $\$ 25,000+$ ) &. &. & $65.27 \%$ & $66.78 \%$ \\
Number of States included in Search & 1 & 36 & 38 & 38 \\
Percent Found & $91 \%$ & $89 \%$ & $92 \%$ & $92 \%$
\end{tabular}

Notes: Enrolled or Employed Full-Time is based on the number of recent baccalaureate graduates who are either employed full-time or continuing their education within one year after graduation. Full-time employment is based on those who earned at least as much as a full-time (40hrs a week) worker making minimum wage. Enrolled or Employed (Earning \$25,000+) is based on the number of recent baccalaureate graduates who are either employed and earned at least $\$ 25,000$ or continuing their education within one year after graduation. The employed data includes non-Florida data that is available from the Wage Record Interchange System 2 (known as "WRIS 2") and Federal employee data that is available from the Federal Employment Data Exchange System (FEDES) initiative. Military employment data was collected by the Board of Governors staff from university staff. Due to limitations in the data, the continuing enrollment data includes any enrollment the following year regardless of whether the enrollment was post-baccalaureate or not. Percent Found refers to the percentage of graduates found in the dataset - including those that did not earn wages above the full-time threshold and those who were found outside of the one-year window.

For more information about the methodology see: http://www.flbog.edulabout/budget/performance_funding.php.

For more information about WRIS2 see: http://www.doleta.gov/performance/wris_2.cfm.

For more information about FEDES see: http://www.ubalt.edu/fif/fedes/.

Median Wages of Bachelor's Graduates Employed Full-time in Florida, One Year After Graduation

\begin{tabular}{lcccc} 
& $\mathbf{2 0 1 0 - 1 1}$ & $\mathbf{2 0 1 1 - 1 2}$ & $\mathbf{2 0 1 2 - 1 3}$ & $\mathbf{2 0 1 3 - 1 4}$ \\
\hline 5th PERCENTILE WAGE & $\$ 17,300$ & $\$ 17,900$ & $\$ 18,400$ & $\$ 18,700$ \\
\hline 25th PERCENTILE WAGE & $\$ 25,200$ & $\$ 25,500$ & $\$ 26,500$ & $\$ 27,200$ \\
\hline MEDIAN WAGE & $\mathbf{\$ 3 3 , 2 0 0}$ & $\mathbf{\$ 3 4 , 6 0 0}$ & $\mathbf{\$ 3 5 , 2 0 0}$ & $\mathbf{\$ 3 6 , 3 0 0}$ \\
\hline 75th PERCENTILE WAGE & $\$ 44,600$ & $\$ 44,000$ & $\$ 46,800$ & $\$ 47,800$ \\
\hline 95th PERCENTILE WAGE & $\$ 64,900$ & $\$ 66,500$ & $\$ 66,600$ & $\$ 67,700$ \\
\hline Percent Found & $53 \%$ & $51 \%$ & $53 \%$ & $54 \%$
\end{tabular}

Notes: Median Wage data is based on Florida's annualized Unemployment Insurance (UI) wage data for those graduates who earned at least as much as a full-time employee making minimum wage in the fiscal quarter a full year after graduation. This $\mathrm{UI}$ wage data does not include individuals who are selfemployed, employed out of state, employed by the military or federal government, or those without a valid social security number. This wage data includes graduates who were both employed and enrolled. Wages rounded to nearest hundreds. Percent Found refers to the percentage of graduates found in the dataset - including those that did not earn wages above the full-time threshold and those who were found outside of the one-year window. 


\section{Section 5 - Graduate Education}

\section{TABLE 5A. Graduate Degree Program Changes in AY 2014-15}

\begin{tabular}{|c|c|c|c|c|c|c|}
\hline Title of Program & $\begin{array}{c}\text { Six-digit } \\
\text { CIP } \\
\text { Code }\end{array}$ & $\begin{array}{c}\text { Degree } \\
\text { Level }\end{array}$ & $\begin{array}{l}\text { Date of } \\
\text { UBOT } \\
\text { Action }\end{array}$ & $\begin{array}{l}\text { Starting } \\
\text { or Ending } \\
\text { Term }\end{array}$ & $\begin{array}{l}\text { Date of } \\
\text { Board of } \\
\text { Governors } \\
\text { Action }\end{array}$ & Comments \\
\hline \multicolumn{7}{|l|}{ New Programs } \\
\hline Athletic Training (Tampa) & 51.0913 & Masters & $6 / 5 / 2014$ & SUMMER 2015 & & \\
\hline Information Studies (Tampa) & 11.0401 & Masters & $6 / 5 / 2014$ & FALL 2014 & & \\
\hline $\begin{array}{l}\text { Rehabilitation Sciences } \\
\text { (Tampa) }\end{array}$ & 51.2314 & $\begin{array}{l}\text { Research } \\
\text { Doctorate }\end{array}$ & $12 / 5 / 2013$ & FALL 2014 & $6 / 19 / 2014$ & \\
\hline Accountancy (St. Pete) & 52.0301 & Masters & 9/5/2014 & SPRING 2015 & & \\
\hline \multicolumn{7}{|l|}{ Terminated Programs } \\
\hline \multicolumn{7}{|l|}{ None } \\
\hline \multicolumn{7}{|c|}{ Programs Suspended for New Enrollments } \\
\hline None & & & & & & \\
\hline \multicolumn{7}{|c|}{ New Programs Considered By University But Not Approved } \\
\hline None & & & & & & \\
\hline
\end{tabular}

Note: This table does not include new majors or concentrations added under an existing degree program CIP Code. This table reports the new and terminated program changes based on Board action dates between May 5, 2014 and May 4, 2015.

New Programs are proposed new degree programs that have been completely through the approval process at the university and, if appropriate, the Board of Governors. Does not include new majors or concentrations added under an existing degree program CIP Code.

Terminated Programs are degree programs for which the entire CIP Code has been terminated and removed from the university's inventory of degree programs. Does not include majors or concentrations terminated under an existing degree program CIP Code if the code is to remain active on the academic degree inventory.

Programs Suspended for New Enrollments are degree programs for which enrollments have been temporarily suspended for the entire CIP Code, but the program CIP Code has not been terminated. Does not include majors or concentrations suspended under an existing degree program CIP Code if the code is to remain active on the academic degree inventory and new enrollments in any active major will be reported. Programs included in this list may have been suspended for new enrollments sometime in the past and have continued to be suspended at least one term of this academic year.

New Programs Considered by University But Not Approved includes any programs considered by the university board of trustees, or any committee of the board, but not approved for implementation. Also include any programs that were returned prior to board consideration by the university administration for additional development, significant revisions, or re-conceptualization; regardless of whether the proposal was eventually taken to the university board for approval. Count the returns once per program, not multiple times the proposal was returned for revisions, unless there is a total re-conceptualization that brings forward a substantially different program in a different CIP Code. 
Section 5 - Graduate Education (continued)

TABLE 5B. Graduate Degrees Awarded

\begin{tabular}{lccccc} 
& $\mathbf{2 0 1 0 - 1 1}$ & $\mathbf{2 0 1 1 - 1 2}$ & $\mathbf{2 0 1 2 - 1 3}$ & $\mathbf{2 0 1 3 - 1 4}$ & $\mathbf{2 0 1 4 - 1 5}$ \\
\hline First Majors & 3,010 & 3,159 & 3,209 & 3,401 & 3,773 \\
Second majors & 0 & 0 & 0 & 0 & 0 \\
\hline TOTAL & $\mathbf{3 , 0 1 0}$ & $\mathbf{3 , 1 5 9}$ & $\mathbf{3 , 2 0 9}$ & $\mathbf{3 , 4 0 1}$ & $\mathbf{3 , 7 7 3}$ \\
\hline Masters and Specialist (first majors) & 2,585 & 2,742 & 2,761 & 2,855 & 3,172 \\
Research Doctoral (first majors) & 269 & 271 & 295 & 330 & 321 \\
Professional Doctoral (first majors) & 156 & 146 & 153 & 216 & 280 \\
\hline Dentistry & 0 & 0 & 0 & 0 & 0 \\
Law & 0 & 0 & 0 & 0 & 0 \\
Medicine & 109 & 112 & 106 & 120 & 124 \\
\hline Nursing Practice & 12 & 6 & 5 & 6 & 12 \\
Pharmacy & 0 & 0 & 0 & 0 & 49 \\
Physical Therapist & 35 & 28 & 42 & 90 & 95 \\
\hline Veterinary Medicine & 0 & 0 & 0 & 0 & 0 \\
Other Professional Doctorate & 0 & 0 & 0 & 0 & 0
\end{tabular}

Note: This table reports the total number of graduate level degrees that were awarded by academic year as well as the number by level. The table provides a breakout for the Professional Doctoral degrees.

\section{TABLE 5C. Graduate Degrees Awarded in Areas of Strategic Emphasis}

[Includes Second Majors]

\begin{tabular}{lccccc} 
& $\mathbf{2 0 1 0 - 1 1}$ & $\mathbf{2 0 1 1 - 1 2}$ & $\mathbf{2 0 1 2 - 1 3}$ & $\mathbf{2 0 1 3 - 1 4}$ & $\mathbf{2 0 1 4 - 1 5}$ \\
\hline STEM & 658 & 730 & 845 & 932 & 1,088 \\
\hline HEALTH & 747 & 729 & 762 & 838 & 1,050 \\
\hline GLOBALIZATION & 27 & 31 & 29 & 25 & 42 \\
\hline EDUCATION & 551 & 572 & 493 & 453 & 455 \\
\hline GAP ANALYSIS & 55 & 66 & 90 & 97 & 107 \\
\hline SUBTOTAL & 2,038 & 2,128 & 2,219 & 2,345 & 2,742 \\
\hline PSE PERCENT OF TOTAL & $\mathbf{6 7 . 7 1 \%}$ & $\mathbf{6 7 . 3 6 \%}$ & $\mathbf{6 9 . 1 5 \%}$ & $\mathbf{6 8 . 9 5 \%}$ & $\mathbf{7 2 . 6 7 \%}$
\end{tabular}

Notes: This is a count of graduate degrees awarded within specific Areas of Strategic Emphasis, as determined by the Board of Governors staff with consultation with business and industry groups and input from universities. This is a count of graduate degrees awarded within specific Programs of Strategic Emphasis, as determined by the Board of Governors staff with consultation with business and industry groups and input from universities - for more information see: http://www.flbog.edu/pressroom/strategic emphasis/. The Board of Governors revised the list of Programs of Strategic Emphasis in November 2013, and the new categories were applied to the historical degrees. A student who has multiple majors in the subset of targeted Classification of Instruction Program codes will be counted twice (i.e., double-majors are included). Note: The denominator used in the percentage includes second majors. 
Section 5 - Graduate Education (continued)

TABLE 5D. Professional Licensure Exams for Graduate Programs

Medicine: US Medical Licensing Exam - Step 1 (for 2nd year MD students)

\begin{tabular}{lccccc} 
& $\mathbf{2 0 1 1}$ & $\mathbf{2 0 1 2}$ & $\mathbf{2 0 1 3}$ & $\mathbf{2 0 1 4}$ & $\mathbf{2 0 1 5}$ \\
\hline Examinees & 110 & 125 & 145 & 147 & Preliminary \\
First-time Pass Rate & $99 \%$ & $91 \%$ & $96 \%$ & $95 \%$ & $97 \%$ \\
National Benchmark & $94 \%$ & $96 \%$ & $97 \%$ & $96 \%$ & $96 \%$
\end{tabular}

Medicine: US Medical Licensing Exam - Step 2 Clinical Knowledge (for $4^{\text {th }}$ year MD students)

\begin{tabular}{lccccc} 
& $\mathbf{2 0 1 0 - 1 1}$ & $\mathbf{2 0 1 1 - 1 2}$ & $\mathbf{2 0 1 2 - 1 3}$ & $\mathbf{2 0 1 3 - 1 4}$ & $\mathbf{2 0 1 4 - 1 5}$ \\
\hline Examinees & 122 & 115 & 152 & 136 & 157 \\
First-time Pass Rate & $99 \%$ & $99 \%$ & $100 \%$ & $98 \%$ & $97 \%$ \\
National Benchmark & $97 \%$ & $98 \%$ & $98 \%$ & $97 \%$ & $95 \%$
\end{tabular}

Medicine: US Medical Licensing Exam - Step 2 Clinical Skills (for $4^{\text {th }}$ year MD students)

\begin{tabular}{lccccc} 
& $\mathbf{2 0 1 0 - 1 1}$ & $\mathbf{2 0 1 1 - 1 2}$ & $\mathbf{2 0 1 2 - 1 3}$ & $\mathbf{2 0 1 3 - 1 4}$ & $\mathbf{2 0 1 4 - 1 5}$ \\
\hline Examinees & 122 & 100 & 128 & 142 & 131 \\
First-time Pass Rate & $100 \%$ & $98 \%$ & $99 \%$ & $91 \%$ & $96 \%$ \\
National Benchmark & $98 \%$ & $97 \%$ & $98 \%$ & $96 \%$ & $96 \%$
\end{tabular}

Note on State \& National Benchmarks: Florida Bar exam pass rates are reported online by the Florida Board of Bar Examiners. Law exam data is based on Feb. and July administrations every calendar year. The State benchmark excludes non-Florida institutions. The USMLE national exam pass rates, for the MD degree from US institutions, is reported online by the National Board of Medical Examiners (NBME). The NAVLE national exam pass rate is reported online by the National Board of Veterinary Medical Examiners (NBVME).

\section{Physical Therapy: National Physical Therapy Examinations}

\begin{tabular}{lccccc} 
& $\mathbf{2 0 0 8 - 1 0}$ & $\mathbf{2 0 0 9 - 1 1}$ & $\mathbf{2 0 1 0 - 1 2}$ & $\mathbf{2 0 1 1 - 1 3}$ & $\mathbf{2 0 1 2 - 1 4}$ \\
\hline Examinees & 81 & 96 & 93 & 92 & 87 \\
First-time Pass Rate & $85 \%$ & $87 \%$ & $90 \%$ & $94 \%$ & $97 \%$ \\
National Benchmark & $87 \%$ & $89 \%$ & $89 \%$ & $90 \%$ & $90 \%$
\end{tabular}

Note: Three-year average pass rates for first-time examinees on the National Physical Therapy Examinations are reported, rather than annual averages, because of the relatively small cohort sizes. 


\section{Section 6 - Research and Economic Development TABLE 6A. Research and Development}

2009-10

2010-11

2011-12

2012-13

2013-14

\section{R\&D Expenditures}

Total (S\&E and non-S\&E)

$(\$ 1,000$ s)

$\$ 390,828$

$\$ 246,016$

Federally Funded

(\$1,000s)

Percent Funded

From External Sources

Total R\&D Expenditures

Per Full-Time, Tenured,

Tenure-Earning Faculty Member (\$)

$\$ 356,595$
$\$ 400,679$

$\$ 451,259$

$\$ 245,410$

$\$ 239,902$

$\$ 228,460$

$62 \%$

$59 \%$

$60 \%$

$\begin{array}{lllll}70 \% & 70 \% & 62 \% & 59 \% & 60 \%\end{array}$

\section{Technology Transfer}

2009-10

2010-11

2011-12

$\$ 421,801$

$\$ 441,400$
Invention Disclosures

161

37

$\$ 17,411,625$

172

177

36

52

$\$ 1,390,871$

$\$ 1,243,425$

$\$ 1,802,233$

$\$ 1,405,713$

Received (\$)

Number of Start-Up Companies

5

8

10

9

11

\begin{tabular}{lccccc} 
& 2010 & 2011 & 2012 & 2013 & 2014 \\
\hline U.S. Patents Issued [REVISED] & 88 & 89 & 84 & 98 & 110 \\
\hline
\end{tabular}

Notes: R\&D Expenditures are based on the National Science Foundation's annual Survey of R\&D Expenditures at Universities and Colleges (data include Science \& Engineering and non-Science \& Engineering awards). Percent Funded from External Sources is defined as funds from federal, private industry and other sources (non-state and non-institutional funds). Total R\&D expenditures are divided by fall, full-time tenured/tenure-track faculty as reported to IPEDS (FGCU includes both tenured/tenure-track and non-tenure/track faculty). The fall faculty year used will align with the beginning of the fiscal year (e.g., $2007 \mathrm{FY}$ R\&D expenditures are divided by fall 2006 faculty). Invention Disclosures reports the number of disclosures made to the university's Office of Technology Commercialization to evaluate new technology - as reported on the Association of University Technology Managers Annual (AUTM) annual Licensing Survey. Licenses \& Options Executed that were executed in the year indicated for all technologies - as reported by AUTM. Licensing Income Received refers to license issue fees, payments under options, annual minimums, running royalties, termination payments, amount of equity received when cashed-in, and software and biological material end-user license fees of $\$ 1,000$ or more, but not research funding, patent expense reimbursement, valuation of equity not cashed-in, software and biological material end-user license fees of less than $\$ 1,000$, or trademark licensing royalties from university insignia - as reported on the AUTM survey. Number of Start-up Companies that were dependent upon the licensing of University technology for initiation - as reported on the Association of University Technology Managers Annual Licensing Survey. REVISED: US Patents Issued awarded by the United States Patent and Trademark Office (USPTO) by Calendar year. 


\section{Section 6 - Research and Economic Development (continued)}

\section{TABLE 6B. Centers of Excellence}

\begin{tabular}{|c|c|c|c|}
\hline Name of Center: & Center for Drug Discovery and Innovation (CDDI) & \multirow{2}{*}{$\begin{array}{l}\text { Cumulative } \\
\text { (since inception } \\
\text { to June 2015) }\end{array}$} & \multirow{2}{*}{$\begin{array}{l}\text { Fiscal Year } \\
2014-15\end{array}$} \\
\hline Year Created: & 2007 & & \\
\hline \multicolumn{4}{|c|}{$\begin{array}{l}\text { Research Effectiveness } \\
\text { Only includes data for activities directly associated with the Center. Does not include the non-Center activities for faculty who are } \\
\text { associated with the Center. }\end{array}$} \\
\hline \multicolumn{2}{|c|}{ Number of Competitive Grants Applied For } & 220 & 26 \\
\hline \multicolumn{2}{|c|}{ Value of Competitive Grants Applied For (\$) } & $\$ 165,138,359$ & $\$ 31,944,210$ \\
\hline \multicolumn{2}{|c|}{ Number of Competitive Grants Received } & 81 & 13 \\
\hline \multicolumn{2}{|c|}{ Value of Competitive Grants Received (\$) } & $\$ 44,626,418$ & $\$ 6,670,092$ \\
\hline \multicolumn{2}{|c|}{ Total Research Expenditures (\$) } & $\$ 20,518,061$ & $\$ 910,204$ \\
\hline \multicolumn{2}{|c|}{$\begin{array}{l}\text { Number of Publications in Refereed Journals } \\
\text { From Center Research }\end{array}$} & 205 & 12 \\
\hline \multicolumn{2}{|c|}{ Number of Invention Disclosures } & 54 & 4 \\
\hline \multicolumn{2}{|c|}{ Number of Licenses/Options Executed } & 12 & 5 \\
\hline \multicolumn{2}{|c|}{ Licensing Income Received (\$) } & $\$ 164,071$ & $\$ 0$ \\
\hline \multicolumn{4}{|c|}{$\begin{array}{l}\text { Collaboration Effectiveness } \\
\text { Only reports on relationships that include financial or in-kind support. }\end{array}$} \\
\hline \multicolumn{2}{|c|}{ Collaborations with Other Postsecondary Institutions } & 76 & 8 \\
\hline \multicolumn{2}{|c|}{ Collaborations with Private Industry } & 105 & 2 \\
\hline \multicolumn{2}{|c|}{ Collaborations with K-12 Education Systems/Schools } & 51 & 3 \\
\hline \multicolumn{2}{|c|}{$\begin{array}{l}\text { Undergraduate and Graduate Students Supported } \\
\text { with Center Funds }\end{array}$} & 108 & 24 \\
\hline \multicolumn{4}{|c|}{ Economic Development Effectiveness } \\
\hline \multicolumn{2}{|c|}{$\begin{array}{l}\text { Number of Start-Up companies } \\
\text { with a physical presence, or employees, in Florida }\end{array}$} & 1 & 0 \\
\hline \multicolumn{2}{|c|}{$\begin{array}{l}\text { Jobs Created By Start-Up Companies } \\
\text { Associated with the Center }\end{array}$} & 5 & 0 \\
\hline \multicolumn{2}{|c|}{ Specialized Industry Training and Education } & 14 & 0 \\
\hline \multicolumn{2}{|c|}{$\begin{array}{l}\text { Private-sector Resources Used to Support } \\
\text { the Center's Operations }\end{array}$} & 0 & 0 \\
\hline
\end{tabular}




\section{Section 6 - Research and Economic Development (continued)}

TABLE 6B. Centers of Excellence (continued)

\section{Name of Center}

Center for Drug Discovery and Innovation (CDDI)

Narrative Comments [Most Recent Year]:

(1) Dr. Bill Baker proceeded on a year's sabbatical to Ireland where at the National University of Ireland, Galway he assisted in the further advancement of their marine biodiscovery research program. (2) CDDI was the recipient of a $\$ 112,555.00$ grant from NuTrae LLC to develop a transdermal patch capable of delivering a smoke free dose of non-psychoactive cannabidiol to patients. (3) CDDI was a Silver Sponsor of the 2014 Annual BioFlorida Conference which was held in Fort Lauderdale, Florida. The conference was attended by over 400 industry professionals from across Florida, the Southeast and the nation. 